\title{
Islamic Republic of Afghanistan: Fifth Review Under the Staff-Monitored Program and Request for an Extension
}

This paper on the fifth review under the staff-monitored program and request for an extension for the Islamic Republic of Afghanistan was prepared by a staff team of the International Monetary Fund as background documentation for the periodic consultation with the member country. It is based on the information available at the time it was completed on October 5, 2005. The views expressed in this document are those of the staff team and do not necessarily reflect the views of the government of the Islamic Republic of Afghanistan or the Executive Board of the IMF.

The documents listed below have been or will be separately released.

Letter of Intent sent to the IMF by the authorities of the Islamic Republic of Afghanistan* Update to the Memorandum of Economic and Financial Policies by the authorities of the Islamic Republic of Afghanistan*

Technical Memorandum of Understanding*

*May also be included in the Staff Report

The policy of publication of staff reports and other documents by the IMF allows for the deletion of market-sensitive information.

To assist the IMF in evaluating the publication policy, reader comments are invited and may be sent by e-mail to publicationpolicy@imf.org.

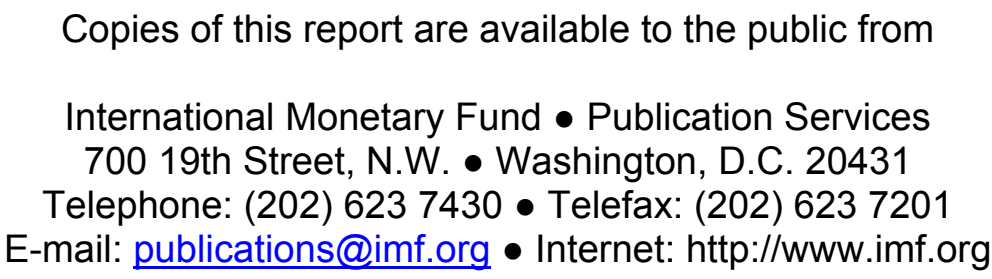

Price: $\$ 15.00$ a copy

\section{International Monetary Fund \\ Washington, D.C.}





\title{
INTERNATIONAL MONETARY FUND
}

\section{ISLAMIC REPUBLIC OF AFGHANISTAN}

\section{Fifth Review Under the Staff-Monitored Program and Request for an Extension}

\author{
Prepared by the Middle East and Central Asia \\ and Policy Development and Review Departments \\ (In consultation with other departments) \\ Approved by Julian Berengaut and Carlo Cottarelli
}

October 5, 2005

- $\quad$ Discussions for the fifth review (April-June 2005) under the Staff-Monitored Program (SMP) were held in Kabul from August 2-16, 2005. The mission met with Vice President Masood, Minister of Foreign Affairs Abdullah, Minister of Finance Ahady, Minister of Economy Farhang, Minister of Commerce Arsala, Da Afghanistan Bank Governor Delawari, other senior government officials, and representatives of nongovernmental organizations and of the donor, business, and diplomatic communities.

- $\quad$ The staff team comprised Messrs. Symansky (head), Bessaha, Martin, Banerjee (all MCD), and Thomas (FAD). The mission was assisted by the resident representative, Mr. Charap, and coordinated with a World Bank mission in the field.

- The security situation has recently deteriorated, particularly outside Kabul. While due in part to the September 18 legislative elections, this deterioration also appears to reflect a resurgence of Taliban activities. No improvement is expected until several weeks after the elections.

- The authorities met all the end-June 2005 indicative quantitative targets and structural benchmarks under the SMP and are requesting a 12-month extension (through September 2006) of the program.

- Staff reached understandings with the authorities on a midyear wage increase for nonuniformed civil servants that is consistent with the move toward medium-term fiscal sustainability and ongoing public administration reforms.

- A donor conference is scheduled for January/February 2006. The agenda and the location of this conference are still under discussion. With the United Nations apparently taking the lead, it is expected that political issues will dominate the agenda.

- Discussions for the sixth review under the SMP and the 2005 Article IV consultation are expected to take place in November 2005, security conditions permitting. 


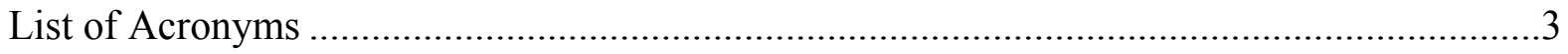

Executive Summary .................................................................................................

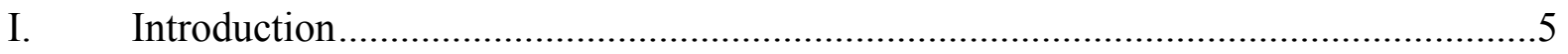

II. Performance Under the Staff-Monitored Program .............................................6

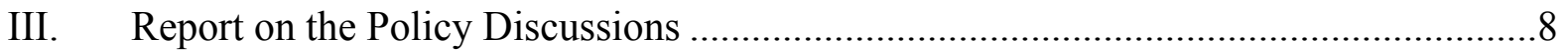

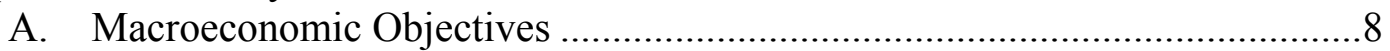

B. Fiscal Policy and Reforms ..................................................................... 8

C. Monetary and Exchange Rate Policy and Financial Sector Reforms ............. 9

D. External Policy and Debt Management …............................................11

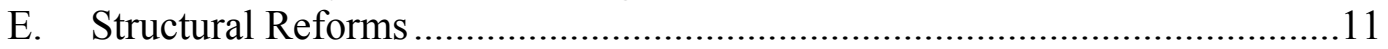

F. Poverty Reduction............................................................................. 12

G. Data Issues and Technical Assistance ....................................................12

H. Program Conditionality and Monitoring..................................................12

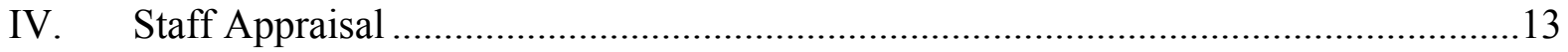

Figures

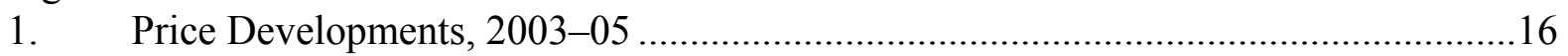

2. Monetary Developments, 2003-05 …............................................................ 17

3. Foreign Exchange Reserves and Real Exchange Rate, 2003-05 ............................ 18

Tables

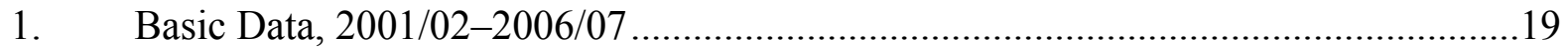

2. Savings-Investment Balances, 2002/03-2007/08 …............................................20

3a. Core Budget (In millions of Afghanis), 2002/03-2006/07 ......................................21

3b. Core Budget (In percent of GDP), 2002/03-2006/07 ..........................................22

4. Monetary Program (Da Afghanistan Bank), 2003/04-2006/07...............................23

5. Balance of Payments, 2002/03-2007/08............................................................24

Appendices

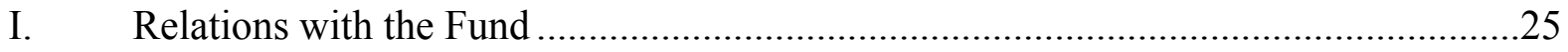

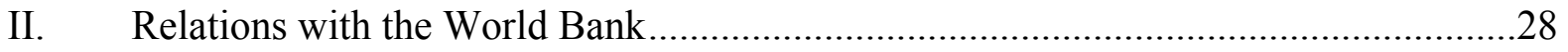

Attachments

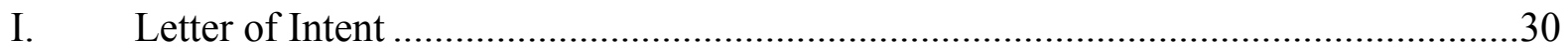

II. Update to the Memorandum of Economic and Financial Policies ............................32

III. Technical Memorandum of Understanding .................................46 


\section{List of Acronyms}

$\begin{array}{ll}\text { CIRR } & \text { Commercial Interest Reference Rates } \\ \text { CSO } & \text { Central Statistics Office } \\ \text { DAB } & \text { Da Afghanistan Bank } \\ \text { GDDS } & \text { General Data Dissemination System } \\ \text { GDP } & \text { Gross Domestic Product } \\ \text { I-PRSP } & \text { Interim Poverty Reduction Strategy Paper } \\ \text { MEFP } & \text { Memorandum of Economic and Financial Policies } \\ \text { MTFF } & \text { Medium-Term Fiscal Framework } \\ \text { MYR } & \text { Midyear Review } \\ \text { NDS } & \text { National Development Strategy } \\ \text { NGOs } & \text { Non-Governmental Organizations } \\ \text { SMP } & \text { Staff-Monitored Program } \\ \text { SOEs } & \text { State-Owned Enterprises } \\ \text { TA } & \text { Technical Assistance } \\ \text { TCC } & \text { Technical Coordination Committee } \\ \text { TMU } & \text { Technical Memorandum of Understanding } \\ \text { TSA } & \text { Treasury Single Account } \\ \text { UNODC } & \text { United Nations Office on Drugs and Crime }\end{array}$




\section{EXECUTIVE SUMMARY}

- The authorities met all the end-June 2005 indicative quantitative targets and structural benchmarks under the Staff-Monitored Program (SMP).

- Economic developments were broadly in line with the program projections made at the time of the fourth review. The growth estimate for 2004/05 was adjusted slightly upwards, to 8 percent, to account for a more buoyant manufacturing sector. Economic activity during the first quarter of 2005/06 appears to be consistent with the 14 percent growth projection for the year, led by a rebound in agriculture due to better winter and spring rainfalls. Year-on-year inflation declined to 11.5 percent at end-June 2005, down from 16.3 percent at end-2004/05, reflecting a sharp slowdown in rent and food prices. It is expected to decline further, to 10 percent by year-end. The real exchange rate remained broadly stable during the first quarter of 2005/06, while fiscal and monetary developments conformed with program objectives. Notwithstanding substantial delays in the resolution/restructuring of the state-owned banks, the implementation of structural reforms has been broadly satisfactory.

- Consistent with the objective of reducing inflation, the monetary program for 2005/06 provides for a further tightening of the monetary stance. The exchange rate will remain flexible. The authorities will pursue the modernization of the banking sector, including through restructuring the state-owned banks that were relicensed, liquidating those that were not, modernizing Da Afghanistan Bank's operations, and creating an enabling environment for lending.

- Opium cultivation is expected to decline significantly in 2005, reflecting in part the authorities' anti-narcotics campaign but also relatively low farm gate prices. The drop in output is expected to be more moderate, due to a rebound in yields. The authorities need to make more progress in their interdiction campaign and in developing alternative livelihoods.

- Staff and the authorities reached understandings on a wage adjustment for nonuniformed civil servants. This adjustment, which will be effective from the second half of 2005/06, is consistent with the move toward medium-term fiscal sustainability and the ongoing public administration reforms.

- In the structural area, several initiatives are being pursued to create an adequate legal framework for private sector investment and activity, and to reduce the share of the public sector in the economy. Progress, however, has been slower-than-envisaged in the program.

- The authorities requested a 12-month extension of the SMP, through end-September 2006. This will provide them with a framework to maintain macroeconomic stability and pursue structural reform. The extension will also give them more time to improve their capacity to implement a formal arrangement and to finalize their work on their national development strategy, which will form the basis for an interim poverty reduction strategy paper.

- Domestic insecurity, the persistence of opium-related activities, and the uncertainty surrounding the composition of the parliament are the main risks for program implementation in the coming months. 


\section{INTRODUCTION}

1. Afghanistan continues to establish a solid track record of macroeconomic policy and structural reforms. The authorities observed all end-June 2005 indicative quantitative indicators and structural benchmarks. All their other policy commitments under the Staff-Monitored Program (SMP), as described in the Memorandum of Economic and Financial Policies (MEFP), were met, except for those related to the former state-owned banks, as no formal decision had been taken regarding their specific resolution process, and to the integration of the former Accounting Department of the Ministry of Finance into the Treasury, whose completion, initially envisaged by end-June, had to be deferred by a few months.

\section{The authorities view their experience under the SMP as helpful and are} requesting an additional 12-month extension of the current program, through end-September 2006. This extension will provide them with a framework to maintain macroeconomic stability, pursue structural reforms, and enhance the statistical database. It will also provide them with sufficient time to continue building the capacity to implement a formal arrangement and to finalize their work on their national development strategy (NDS), which will form the basis for an interim poverty reduction strategy paper (I-PRSP). It is understood that Afghanistan is not precluded from entering into a program supported by the Poverty Reduction and Growth Facility or another formal arrangement before the SMP expires, in particular once the I-PRSP is finalized.

3. The authorities are aware that the pursuit of sound macroeconomic policies and structural reforms is critical to sustain long-term growth and reduce poverty. Notwithstanding the risks associated with continued domestic insecurity, persistent opium-related activities, and working with a newly-elected parliament, they are committed to safeguard macroeconomic stability and focus on:

- $\quad$ Fiscal sustainability: domestic revenue remains exceptionally low by international standards and covers only slightly more than half of operating expenditures. Unless a significant effort is made by the government to meet its objective of covering its operating expenditures with its own resources within a few years, it will face the risk that donor support could wane quickly. At the same time, the government may have to resist persistent pressures from the business community and potential investors to reduce tax rates and import duties. Given the country's significant spending needs, the government also needs to prioritize its expenditures within the available domestic and donor resources and ensure these are used effectively.

- Monetary stability: although limited in its instruments, monetary policy has been effective in containing inflation and exchange rate volatility. As the financial sector develops, the authorities will have to review the monetary instruments and operational objectives in order to strengthen Da Afghanistan Bank's (DAB) control over liquidity. 
- External sustainability: even under the assumption of a "clean slate" for existing bilateral debts and claims, external sustainability could be at risk unless there are strong economic and revenue performances and the government financing strategy continues to rely on grants and borrowing at highly concessional terms.

- Diversification of sources of growth: in the immediate post-conflict environment, wheat production, construction, and some service activities have been the main contributors to economic growth. While activity in these sectors will continue to provide some impetus to growth over the next few years, it will be insufficient over the long term to sustain growth and alleviate poverty.

- External competitiveness: the Afghani appreciated by 15 percent in real terms against the U.S. dollar during 2004/05. This real appreciation, along with the relatively high level of wages, notably for qualified workers and in agriculture, appears largely attributable to the impact on aggregate demand and labor demand of significant donor- and drug-related inflows. Unless these inflows are accompanied by substantial gains in productivity and lower factor costs, this real appreciation will weaken external competitiveness and diminish the opportunities for exports and further growth.

- Credit markets: while there is already a Banking Law, the development of credit markets, and hence the expansion of the private sector, is constrained by a weak regulatory and institutional framework. The current favorable growth environment suggests there is room to support further legal and regulatory reforms and progress in building a resilient banking system.

\section{Performance Under the Staff-Monitored Program}

\section{Macroeconomic performance was in line with program projections}

(Tables 1 and 2). Real GDP growth for 2004/05 was revised upwards to 8 percent and economic activity during the first quarter of 2005/06 appears in line with the real GDP growth projection for the year (13.6 percent). Inflation declined in Kabul during the first quarter of 2005/06 (see paragraph 3 of MEFP and Figure 1) to 11.5 percent at end-June 2005, from 16.3 percent at end-2004/05. This decline, which was largely expected, essentially reflected the sharp slowdown in rent and food prices. Opium cultivation is expected to decline significantly in $\mathbf{2 0 0 5}$, due in part to the authorities' anti-narcotics campaign and to relatively low farm gate prices. Nonetheless, the decline in production is expected to be more moderate, due to a rebound in yields (see paragraph 6 of the MEFP). ${ }^{1}$

\footnotetext{
1 The United Nations Office on Drugs and Crime (UNODC) preliminary estimates for 2005, released on August 29, were broadly in line with these expectations: opium cultivation declined by 21 percent in 2005 , while production declined by 2 percent.
} 
5. Fiscal revenue for the first quarter of $2005 / 06$ is estimated at $\mathrm{Af} 4,757$ million, slightly exceeding the SMP indicative target of Af 4,629 million (see paragraphs 7-9 of the MEFP and Tables 3a and 3b). This outcome was achieved despite a decline in domestic tax revenue as a result of a 40 percent increase in customs revenue over the same period of last year. Core budget operating spending amounted to Af 6.6 billion, compared with an annual budget projection of Af 32.9 billion. $^{2}$ The operating budget, including grants, recorded a small deficit in the first quarter, which was covered by a drawdown of domestic deposits. The supplementary development budget adopted in June provided for a substantial increase in expenditures over last year. Development spending remained, however, significantly lower than budgeted, essentially due to the lack of security, the low capacity of line ministries and other implementing agencies to develop and implement projects, and unrealistic budget formulation.

6. Monetary developments were broadly in line with program projections. Currency in circulation reached Af 40.1 billion at end-June, compared with a projection of Af 39.2 billion and a ceiling of Af 41.2 billion (see paragraph 12 of MEFP, Figure 2, and Table 4). International reserves continued to increase, to $\$ 1.3$ billion at end-June, (equivalent to 3.8 months of 2006/07 imports). During the first quarter, the interest rate on the overnight capital note remained low at 1-2 percent. The rate on the 30 -day note rose slightly, fluctuating between 5-6 percent, triggering the participation of some foreign-owned private banks to the 30-day note auctions. While the Afghani depreciated slightly against the U.S. dollar over the quarter, the real exchange rate remained broadly unchanged.

\section{The current account deficit, excluding grants, declined to 45 percent of GDP in} $\mathbf{2 0 0 4 / 0 5}$, from 50.9 percent of GDP in 2003/04, on account of a slowdown in imports (Table 5). This slowdown was largely attributable to a decline in smuggled imports reflecting some improvement in border control. Including grants, the current account recorded a surplus equivalent to 0.7 percent of GDP in 2004/05, down from 3.1 percent of GDP in 2003/04. Foreign direct investment increased substantially, albeit from a low base. External borrowing remained limited and highly concessional.

8. Progress in implementing structural reforms was mixed. In the fiscal area, the authorities promulgated in June 2005 the new public financial management law and have begun issuing monthly statements of fiscal performance for the core budget. However, the integration of the former Accounting Department of the Ministry of Finance into the Treasury, initially envisaged by end-June 2005 , will not be completed for several months as the restructuring plan has to be submitted to and approved by the Independent Administrative Reform and Civil Service Commission (see paragraph 11 of the MEFP). In the banking area, while the authorities made headway in rationalizing DAB's balance sheet, modernizing its operations and in strengthening the monetary policy institutional framework, little progress was made in resolving the former state-owned banks and in restructuring the

\footnotetext{
${ }^{2}$ The Ministry of Finance staff are currently evaluating the reasons for the shortfall in domestic tax revenue.
} 
licensed ones (see paragraph 13 of the MEFP). In particular, while the authorities indicated their intention to liquidate the three former state-owned banks, a formal decision had yet to be taken and there were efforts within the government and by some donors to revive the Agricultural Development Bank as a way to develop rural financing and facilitate the implementation of the alternative livelihood programs.

\section{Report on the Policy Discussions}

9. The focus of the discussions for the fifth review was threefold: (a) the extension of the SMP to maintain a framework for macroeconomic discipline and the pursuit of structural reforms, and to build further capacity; (b) the government's reform priorities to accelerate growth and poverty reduction; and (c) the adjustment of public wages envisaged for the second half of 2005/06.

\section{A. Macroeconomic Objectives}

10. The growth outlook for $\mathbf{2 0 0 5 / 0 6}$ remains favorable. In view of the recovery in agriculture and sustained activity in construction, telecommunications, and transport, staff and the authorities agreed on maintaining the real GDP growth projection for 2005/06 at 13.6 percent. For $2006 / 07$, on the assumption that agricultural growth returns to its trend, economic growth is projected to decline slightly, to 11.2 percent. With rents and food prices expected to continue to slow down, and the pursuit of a tightening of the monetary stance, year-on-year inflation is projected to decline to 10 percent by end-2005/06 and 8 percent by end-2006/07. GDP per capita would increase to $\$ 342$ in 2006/07, from $\$ 253$ in 2004/05.

11. Staff and the authorities reached understandings on: (a) an updated mediumterm macroeconomic framework for 2005/06-2007/08; and (b) consistent with the request for a 12-month extension of the SMP, a set of new quantitative indicators and structural benchmarks through end-September 2006.

\section{B. Fiscal Policy and Reforms}

12. The authorities' fiscal strategy aims at strengthening revenue collection. Staff and the authorities agreed that full implementation of the customs and tax administration reform programs is critical to reach the SMP revenue projection for $2005 / 06$, which at 5.2 percent of GDP is higher than the budget projection. ${ }^{3}$ The authorities concurred with staff on the need to focus, as part of the immediate revenue effort, on strengthening the large taxpayer unit, establishing tax enforcement powers by end-September 2005, and improving tax and customs administration and infrastructure, including through the implementation of

\footnotetext{
3 The increase in revenue is due in part to the collection in 2005/06 of the overflight fees accrued in 2004/05 (Af 800 million). Excluding this exceptional revenue, the projected increase in revenue is consistent with the authorities' objective of covering the wage bill within four years.
} 
the recently approved tax measures and the continued roll-out of the tax identification number system. Looking ahead, an improved revenue outlook would come from the elimination of the plethora of "nuisance taxes," the strengthening of the monitoring of the exemption system, and the extension of the tax base, possibly through the introduction of excise taxes (see paragraphs 23 and 24 of the MEFP). The authorities took note of these suggestions. They also indicated that they were under intense pressure by the business community and potential investors to reduce taxes so as to compensate for a lack of infrastructure, the unstable environment, and costs associated with corruption. The Minister of Finance is planning on convening a revenue policy conference in October to discuss various options.

\section{To partially compensate for the real erosion of public wages - the last wage} increase was granted in November 2003 - the authorities decided to adjust wages for nonuniformed civil servants at the time of the midyear review (MYR). Understandings were reached to restrict this adjustment to no more than Af 600 million in 2005/06 (equivalent to 3 percent of operating budget salary costs), to be financed from the expected surplus in domestic revenues compared with budget estimates. Such a wage adjustment would not unduly compromise the move toward fiscal sustainability and should be consistent with the ongoing public administration reforms.

14. The authorities committed to adopt by end-December 2005 a clear, affordable, and realistic medium-term fiscal framework (MTFF). The MTFF will be instrumental in integrating macroeconomic and fiscal targets, leading the way toward fiscal sustainability. More realistic budget formulation, particularly regarding development expenditures, would also enhance the credibility of the budget as a policy tool and help to manage growing public expectations. This might also encourage donors to channel more funds through the budget (see paragraph 20 of the MEFP).

\section{Monetary and Exchange Rate Policy and Financial Sector Reforms}

\section{While reiterating the importance of a flexible monetary policy, the authorities} agreed with staff to keep the monetary program for $2005 / 06$ unchanged. The program, which was prepared at the time of the third review, provides for a further tightening of the monetary stance during the remainder of the year, consistent with DAB's primary objective to bring inflation under 10 percent by year-end. ${ }^{4}$ The authorities concurred with staff that a more restrictive approach during the first quarter might have been warranted - so as to generate more room to accommodate the expected sharp seasonal increase in money demand during the remainder of the first semester and thereby reduce the risk of a large appreciation stemming from substantial foreign exchange intervention. Staff and the authorities also agreed that, as the financial sector develops, there will be a need to shift to a broader

\footnotetext{
${ }^{4}$ The growth of currency in circulation is projected to decline from 35.8 percent year-on-year at end-June 2005 to 27.8 percent year-on-year at end-2005/06.
} 
intermediate target (e.g., broad money) and to expand the set of monetary instruments, but that, at this stage, the current monetary framework remained adequate. The monetary program will remain flexible, allowing the authorities to accommodate, to a certain extent, unanticipated shifts in the demand for currency, and the exchange rate will continue to be market-determined. International reserves are expected to increase further, to about $\$ 1.7$ billion at end-2005/06, equivalent to 4.8 months of $2006 / 07$ imports.

16. The authorities committed to pursue the rationalization of DAB's balance sheet and the modernization of its operations. In particular, they agreed to reimburse, transfer to other entities, or freeze, commercial accounts in DAB's Kabul branches as well as in other branches located in provinces where at least one fully-licensed commercial bank operates. In addition, DAB will process the gold held in the palace vaults into a form that qualifies as a reserve asset, and to transfer the monetary gold held in Afghanistan to an international gold center. This will rationalize further DAB's balance sheet and allow a proper assessment of its capital adequacy. In line with the recommendations of the recent MFD technical assistance mission on monetary policy, DAB will introduce an overnight collateralized credit facility against capital notes and allow participants in the foreign currency auctions to sell, as well as to buy, U.S. dollars. Should the demand for capital notes continue to increase, DAB could introduce longer-maturity notes. Lastly, consistent with the authorities' commitment to transparency, the capital note interest rates will be published.

17. The authorities intend to tackle the administrative and legal impediments to the development of the banking sector. Toward this end, they will work with the banking and donor communities to strengthen the banking sector regulatory and institutional framework. Acknowledging that poor enforcement of existing laws may in some cases be a strong deterrent to lending activities, the authorities intend, in particular, to determine for each key law (mortgage law, insurance law, land titling and property registration law) whether it needs to be amended and/or which measures are needed to ensure proper enforcement. The authorities also saw the need to eliminate the very high registration fees for deeds, or at least to reduce them sufficiently to bring them in line with international standards.

\section{The authorities committed to intensify their efforts to resolve the former} state-owned banks and to restructure the licensed state-owned banks. While emphasizing Afghanistan's substantial rural financing needs, the authorities agreed with staff that these needs would be best served by means other than creating a sectoral bank. Accordingly, they indicated that they had decided to liquidate the three former state-owned banks, including the Agricultural Development Bank, and that they will issue shortly a statement to that effect. The authorities also reaffirmed their commitment to prepare a longterm strategic plan for the restructuring of the three state-owned banks with a clear implementation timetable. In addition, they will assign new management teams or engage management advisors to implement this plan. 


\section{External Policy and Debt Management}

19. Staff and the authorities agreed that external sector prospects remain favorable. Reflecting a relatively strong economic recovery and a pick-up in exports, the current account deficit, excluding grants, is projected to reach 44.8 percent of GDP in $2005 / 06$, compared with 45 percent of GDP a year before. Including grants, the current account is expected to record a surplus of 0.5 percent of GDP in 2005/06. Over the medium term, the current account deficit, excluding grants, is expected to continue to improve on account of a sustained rise in exports, a decline in imports related to donor-financed activities, and the substitution of some imports with domestically-produced goods. As a result, the current account deficit excluding grants would decline to 31 percent of GDP by 2007/08. The team endorsed the authorities' renewed commitment to continue to rely only on grant financing and highly concessional borrowing. In line with this approach, external borrowing is expected to remain relatively modest over the medium term.

20. Staff noted that efforts continue to be made to complete the external debt survey and design an external debt management strategy. In particular, staff welcomed the government's initiative to liaise closely with the Paris Club Secretariat to ensure that there are no obligations outstanding vis-à-vis Paris Club creditors. For non-Paris Club creditors, staff was encouraged by the renewal of contacts with those that did not respond to earlier requests for debt reconciliation. The authorities asked staff for assistance to facilitate their exchanges with officials of the non-Paris Club creditors. Staff also welcomed the first draft of an external debt management strategy that will be submitted to Cabinet. ${ }^{5}$

\section{E. Structural Reforms}

21. The authorities intend to pursue their efforts aimed at improving the business climate. The establishment of a modern and simplified tax system, together with improved procedures for enterprise creation and an adequate legal framework for private sector investment and activity, will help address some of the difficulties facing investors. To better address these difficulties, the authorities are also preparing, in collaboration with the World Bank, an investment climate assessment. The expected adoption by end-September 2005 of an overall economic restructuring plan and a classification of state-owned enterprises (SOEs) by envisaged restructuring method is a right step toward reducing the role of government in the economy. The authorities concurred with staff that the retrenchment program being designed to accompany the government's divesting from SOEs should be fiscally sustainable and that it will likely set the precedent for future civil service retrenchment.

\footnotetext{
${ }^{5}$ Once the debt strategy is adopted, staff will explore with the authorities the possibility of a structural benchmark related to its implementation.
} 


\section{F. Poverty Reduction}

22. Staff discussed with the authorities their work on the NDS, which will form the basis of an I-PRSP slated for completion by end-December 2005. This ambitious timetable reflects the authorities' intention to submit their development strategy priorities to the donor conference scheduled for January/February 2006. The team noted the extensive consultation process that was put in place. Looking forward, efforts and priorities should be shifted to analyzing (a) the determinants of poverty; (b) the sources of growth; and (c) ways to integrate medium-term fiscal choices, within a MTFF.

\section{G. Data Issues and Technical Assistance}

23. Despite recent progress, data provision and quality remain weak. The government is taking steps to build an adequate statistical base, and a set of measures are under way to help implement the statistical master plan adopted in September 2004. Key among these measures is the restructuring of the Central Statistical Office (CSO). However, some key government officials still do not see the need at this juncture for an independent agency. Staff emphasized that, in the absence of an independent CSO, donor support and progress in this area will be slow. In any case, the authorities intend to adopt by end-September 2005 a statistical law providing the adequate legal framework for data collection, processing, and publication, and to launch before the end of the year key economic surveys (see paragraph 31 of MEFP). Those surveys are needed to assess progress in tackling poverty reduction. Lastly, the government is taking steps to join the General Data Dissemination System (GDDS).

24. The authorities intend to finalize by year-end the ongoing assessment of the technical assistance (TA) received so far. The findings of this review will provide the basis for a much-needed redeployment of TA resources and address the needs of the other government agencies. As elections approach and security becomes more volatile, provision of TA could be somewhat disrupted. Nonetheless, staff reiterated the Fund's willingness to continue to provide TA in support of the authorities' economic reforms.

\section{H. Program Conditionality and Monitoring}

25. Conditionality includes quarterly indicative quantitative targets and structural benchmarks through end-September 2006, which are set out in Tables 1 and 2 of the MEFP. The sixth review under the SMP, tentatively scheduled for November 2005, will assess quantitative performance and observance of structural conditionality through end-September 2005. A Technical Memorandum of Understanding (TMU) provides the details of the program design and terminology. The authorities will continue to make available to Fund staff all data as specified in the TMU. 


\section{Staff Appraisal}

26. Afghanistan's performance under the program continues to be commendable. All end-June 2005 indicative quantitative targets and structural benchmarks were met. A rebound of the economy appeared to be taking hold during the first months of 2005/06, spearheaded by the recovery in the agricultural sector. Some headway has been made in reducing opium cultivation. Growth prospects for the medium term are favorable, reflecting the reconstruction effort, continued donor support, and sustained activity in construction and services. Fiscal policy and monetary developments remain on track. Notwithstanding substantial delays in the resolution/restructuring of the state-owned banks, the implementation of structural reforms has been satisfactory.

\section{The main challenge for Afghanistan is to maintain high growth rates and make} inroads in alleviating poverty. This will require persevering with the stabilization effort and working to improve the investment environment by lowering the cost of doing business and squarely addressing the risks posed by the drug economy, the lack of infrastructure, cumbersome procedures hindering private investment, and the lingering insecurity. Working with a parliament will likely provide the government with additional challenges.

\section{The authorities should intensify their efforts aimed at eliminating the drug} economy. While partly due to relatively low farm gate prices, staff commended the authorities for the decline in opium cultivation, which validated their multi-pronged approach, combining eradication, interdiction, and alternative livelihoods. Staff emphasized, however, that there was no room for complacency as these gains could quickly reverse, especially if farm gate prices start increasing or/and if the farmer's expectations in terms of alternative livelihoods are not met. The government and donors must continue their efforts and come up with new initiatives to firmly establish an irreversible trend in the fight against drug activities.

29. The fiscal program for $\mathbf{2 0 0 5 / 0 6}$ remains sound. By maintaining the "no overdraft" financing rule for the 2005/06 budget, the authorities are required to fund the core budget mainly through domestic revenues and grants. ${ }^{6}$ They are broadly on track to achieve the SMP revenue-to-GDP ratio of 5.2 percent, but it will require implementation of tax and customs reform measures and the collection of the overflight fees accrued in 2005/06. Staff commended the government for taking important revenue-raising initiatives in the run-up to legislative elections and for considering the elimination of nuisance taxes and the introduction of excise taxes in the near future. Staff also emphasized that the current structure of major taxes was relatively competitive and that, in view of the objective to raise revenue and the availability of alternative instruments to attract investment, a downward revision of tax rates seemed unwarranted. The pressure for additional expenditures remains

\footnotetext{
${ }^{6}$ In the event of an unexpected liquidity shortage, the government can drawdown some of its deposits with DAB, which were estimated at about Af 20 billion at end-June 2005.
} 
high, both for wages and infrastructure investments. The space for the wage adjustment is limited. It should come from additional domestic revenue and should be consistent with longterm public administration reforms.

30. Looking at the medium term, the development of a realistic and affordable MTFF should be at the center of the fiscal strategy in support of the NDS. The MTFF is predicated on the development of comprehensive sustainable fiscal and sectoral policies. Therefore, it will be important that donors provide more timely information on expenditures currently outside the core budget. A regular update of the MTFF would also enhance its efficiency.

\section{Staff encouraged the authorities to pursue the modernization of DAB's} operations and the rationalization of its balance sheet. Staff welcomed the significant progress made in modernizing the foreign exchange and capital note auctions, in restructuring DAB's balance sheet, in collecting banking data, and in enhancing transparency. This progress has already led to an increased participation of the commercial banks to the auctions, allowing foreign exchange and interest rates to better reflect market conditions. Drawing from MFD TA recommendations, the authorities could extend DAB's set of monetary instruments and improve the effectiveness of those already in place. Lastly, staff welcomed the authorities' commitment to process the gold held in the palace vaults and to transfer the monetary gold to an international gold center, as it will allow DAB to increase its international reserves and ensure adequate capitalization.

\section{The authorities should tackle the impediments to the development of the} banking sector and be more involved in reforming the state-owned banks. Staff welcomed the authorities' commitments to work with the banking and donor communities to create an enabling environment for lending operations, and to eliminate, or reduce substantially, the registration fees for deeds, which are a major deterrent to lending as well as a major source of corruption. Staff reiterated their concerns about the lack of progress in reforming the state-owned banks, which appears to reflect in part a lack of political will, and urged the authorities to intensify their efforts. Staff was therefore encouraged by the authorities' commitments to liquidate the former state-owned banks and to assign new management teams, or engage management advisors, to implement the restructuring plan for the licensed state-owned banks. The authorities should consider all options for these licensed banks, including the liquidation or privatization of some, or all, of them. Lastly, DAB should ensure that the conditions attached to the relicensing of these banks are strictly met.

\section{An inadequate business environment remains a serious constraint to growth}

prospects. The authorities' focus on reforms aimed at addressing some of the difficulties facing investors is welcome, as is their continued commitment to divest from many of the SOEs. Introducing a sustainable retrenchment program for the employees of these enterprises would be important to facilitate the divestment process while preserving fiscal sustainability. However, staff are concerned that the political will to carry out this reform program is not widely shared within the Cabinet, and, more generally, that recent legal setbacks may slow down privatization and business reform. At the same time, the government also needs to 
eliminate its involvement in commercial activities conducted directly by government ministries or by public entities not classified as SOEs. ${ }^{7}$

34. Afghanistan has taken action to address the issues of reliability and timeliness of economic statistics, but there are still weaknesses in many areas. Staff welcomed the corrective measures underway. The authorities' intention to join the GDDS is a positive step in this direction. On the issue of the independence of the CSO, staff reiterated the importance of adopting the statistical law.

35. The technical coordination committee is continuing to improve its understanding of the Afghan economy. In the future, it will be important that the committee expands its role and focus its attention on analytical issues. Staff support the intention of the committee to coordinate closely on the macroeconomic impact of the NDS.

36. The authorities recognized that the SMP has helped them establish and maintain macroeconomic stability, coordinate donor activity, and create the momentum for sustained structural reforms. Considering also the need for the new members of parliament to familiarize themselves with the various economic issues facing the country, the authorities requested a further 12-month extension of the current SMP. Staff supported this request and observed that this should not preclude entering into a formal arrangement at any point during the extension period, in particular once the I-PRSP is finalized.

37. Together with the discussions for the 2005 Article IV consultation, discussions for the sixth review under the SMP will take place in November 2005. The findings of the MYR, fiscal and external sustainability, external competitiveness, tax and customs reforms, the macroeconomic effects of a successful anti-narcotics policy, and bank restructuring will be the main areas on which staff will focus its attention.

\footnotetext{
7 The SOEs only include the enterprises fully and directly owned by the government. They do not include other enterprises, like Ariana Afghan Airlines, in which the government is the majority but not sole shareholder; nor government departments conducting commercial activities (e.g., producing military clothing).
} 
Figure 1. Islamic Republic of Afghanistan: Price Developments, 2003-05 1/

\section{Consumer Price Index}

(Year-on-year change; in percent)
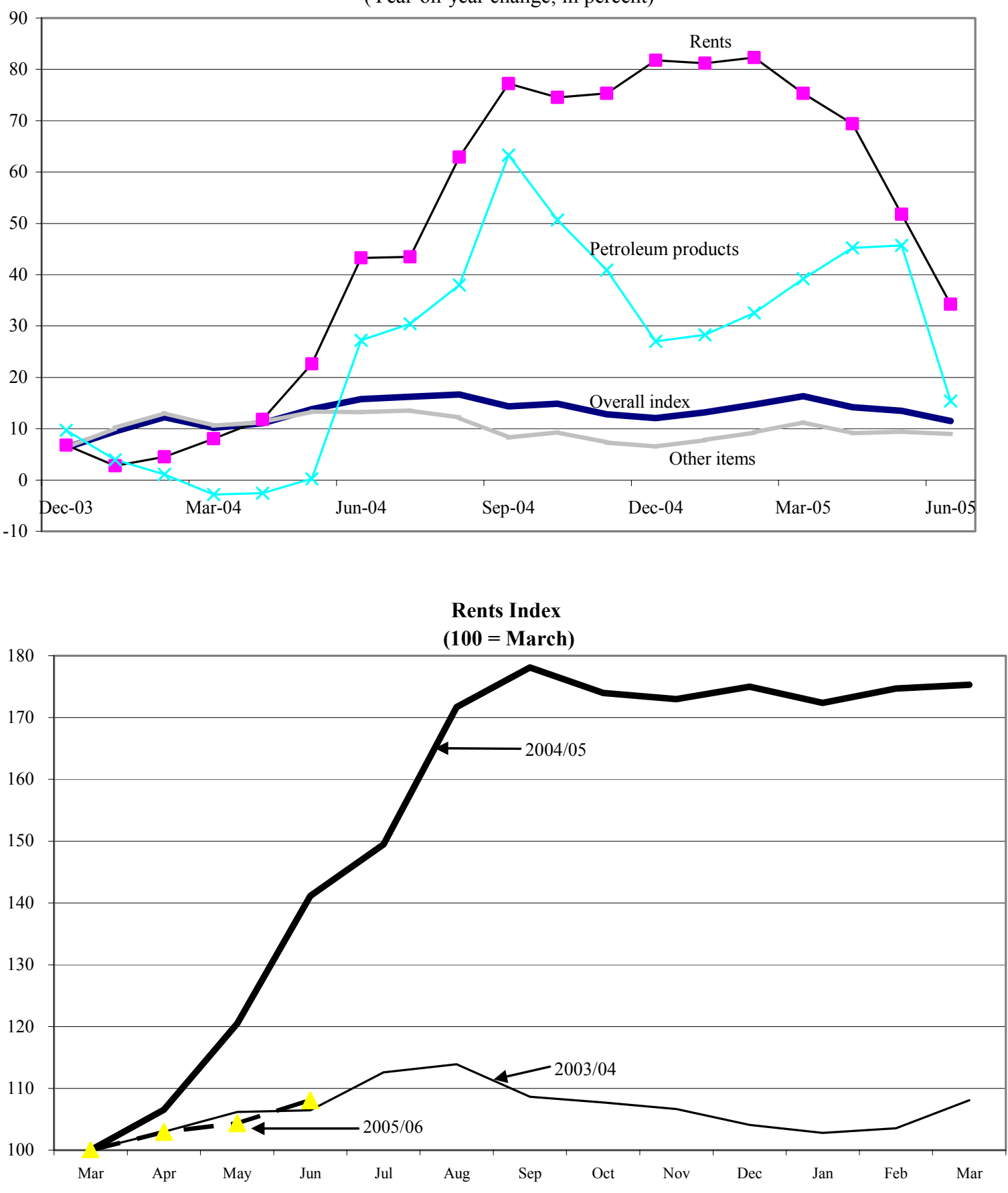

Sources: Central Statistics Office of Afghanistan; and Fund staff estimates.

1/ Last observation: June 2005. 
Figure 2. Islamic Republic of Afghanistan: Monetary Developments, 2003-05 1/
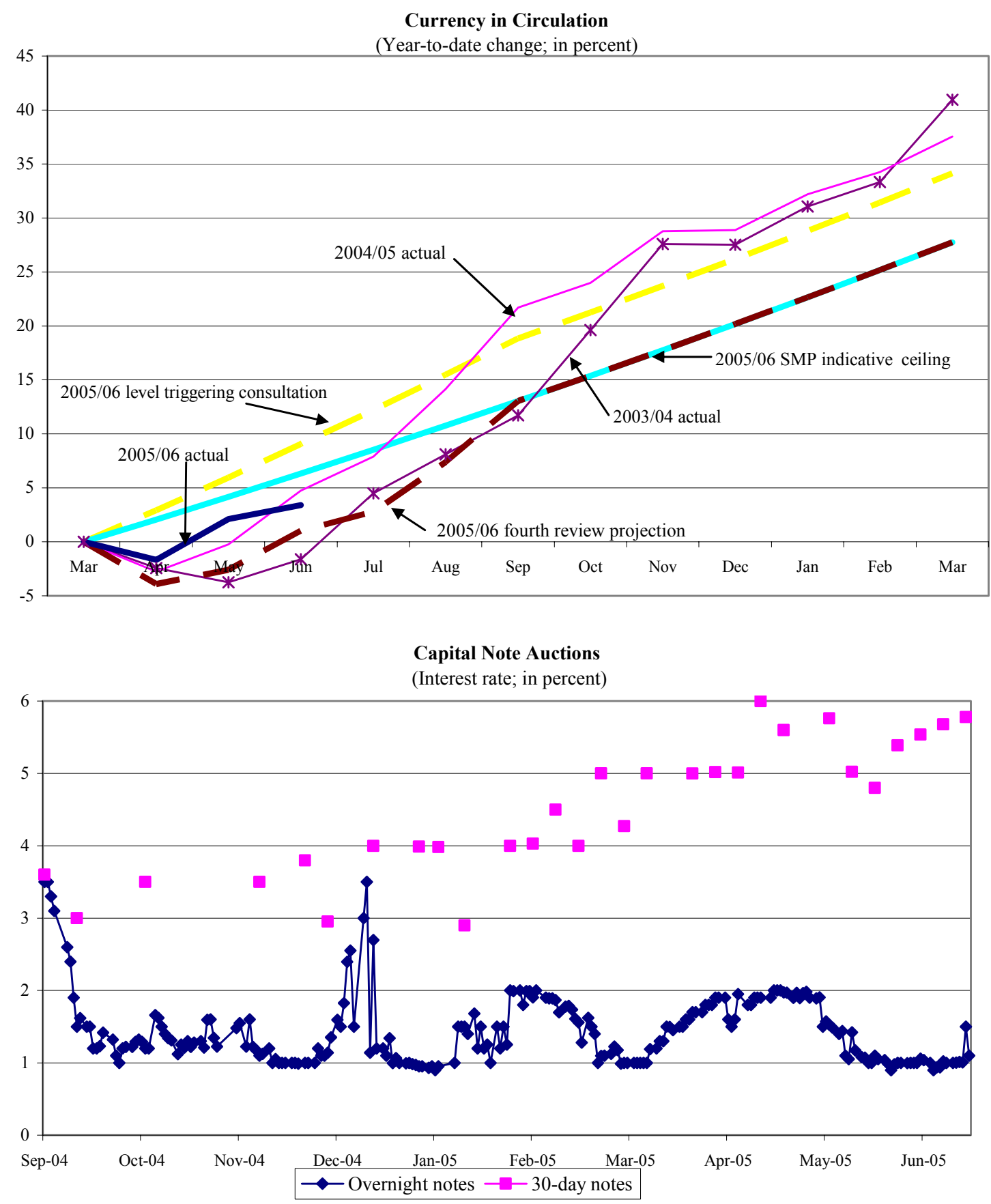

Sources: Da Afghanistan Bank; and Fund staff estimates and projections.

1/ Last observation: June 30, 2005. 
Figure 3. Islamic Republic of Afghanistan: Foreign Exchange Reserves and Real Exchange Rate, 2003-05 1/

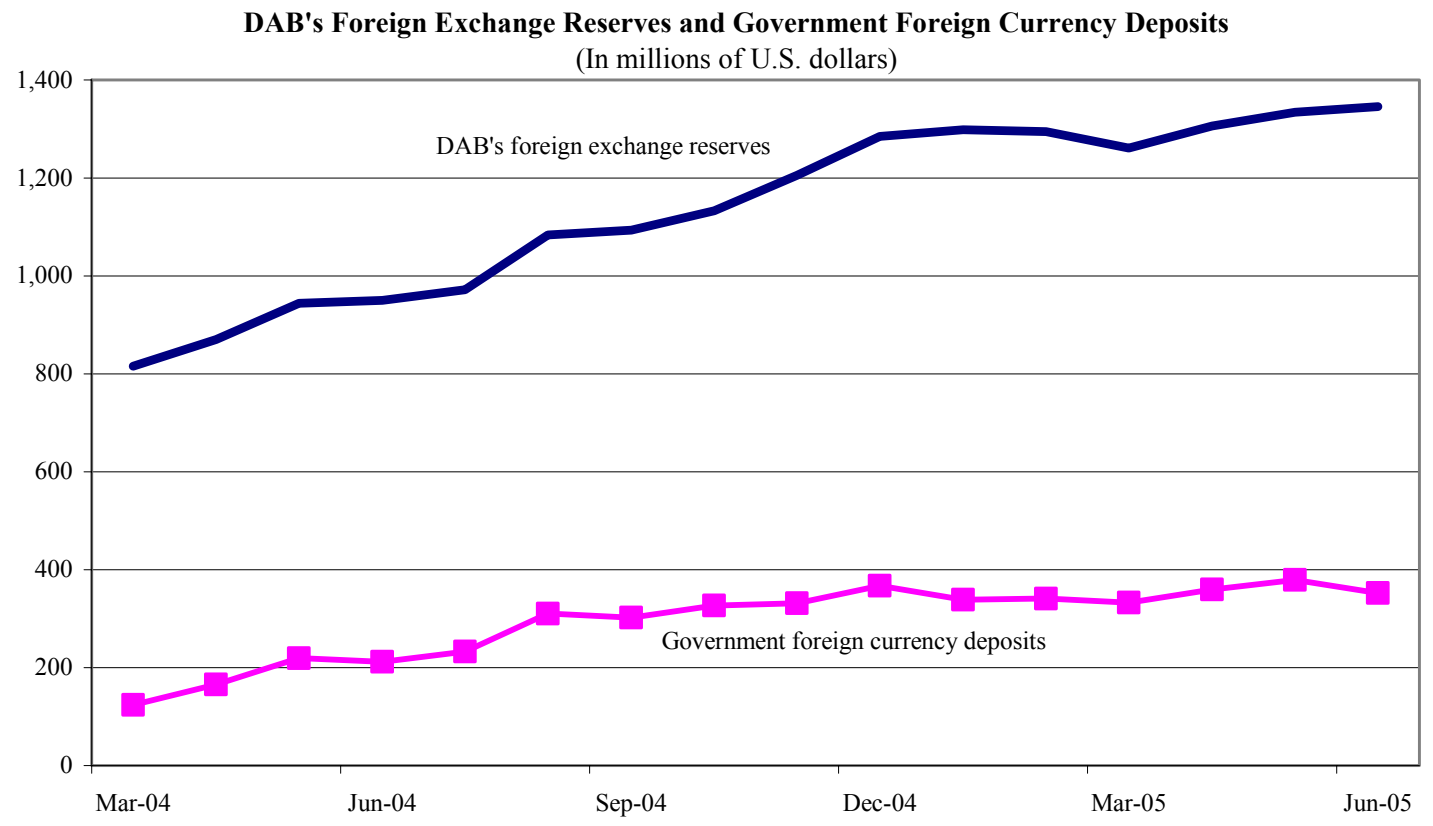

Price and Exchange Rate Indices 2/

(March $2004=100)$

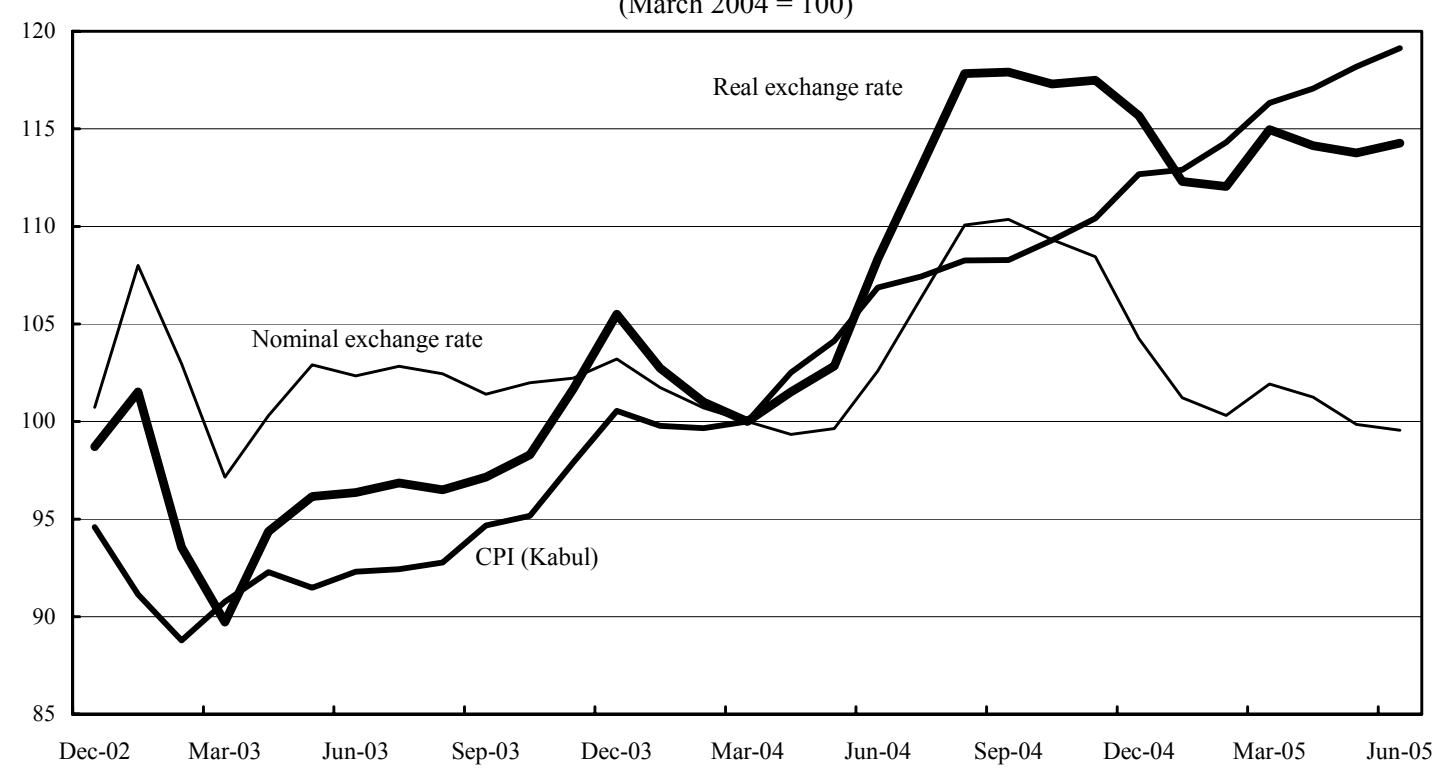

Sources: Central Statistics Office of Afghanistan; Da Afghanistan Bank; and Fund staff estimates.

1/ Last observation: June 20, 2005.

2/ An increase in the exchange rate indices corresponds to an appreciation. The real exchange rate is estimated using the U.S. and Afghan CPIs. 
Table 1. Islamic Republic of Afghanistan: Basic Data, 2001/02-2006/07 1/

\begin{tabular}{|c|c|c|c|c|c|c|}
\hline & $\begin{array}{r}2001 / 02 \\
\text { Est. }\end{array}$ & $\begin{array}{r}2002 / 03 \\
\text { Est. }\end{array}$ & $\begin{array}{r}2003 / 04 \\
\text { Est. }\end{array}$ & $\begin{array}{r}2004 / 05 \\
\text { Est. }\end{array}$ & $\begin{array}{r}\text { 2005/06 } \\
\text { Proj. }\end{array}$ & $\begin{array}{r}2006 / 07 \\
\text { Proj. }\end{array}$ \\
\hline \multicolumn{7}{|c|}{ I. Economic and Financial Indicators } \\
\hline \multicolumn{7}{|l|}{ Production } \\
\hline GDP (in millions of U.S. dollars, excluding opium production) & 2,463 & 4,084 & 4,585 & 5,971 & 7,130 & 8,562 \\
\hline GDP (in millions of Afghanis) & 133,987 & 182,862 & 225,108 & 284,504 & 355,338 & 426,668 \\
\hline Real GDP growth rate (in percent) & $\ldots$ & 28.6 & 15.7 & 8.0 & 13.6 & 11.2 \\
\hline GDP per capita (in U.S. dollars) & 123 & 182 & 199 & 253 & 293 & 342 \\
\hline Opium production (in metric tons) & 200 & 3,400 & 3,600 & 4,200 & $\ldots$ & $\ldots$ \\
\hline Opium value (in millions of U.S. dollars) & $\cdots$ & 2,540 & 2,300 & 2,800 & $\ldots$ & ... \\
\hline \multicolumn{7}{|l|}{ Consumer prices } \\
\hline CPI (Kabul, year-on-year change; in percent ) & -43.4 & 52.1 & 10.2 & 16.3 & 10.0 & 8.0 \\
\hline CPI (Kabul, average change; in percent) & $\cdots$ & 5.0 & 23.9 & 14.3 & 11.2 & 8.9 \\
\hline \multicolumn{7}{|c|}{ (In millions of Afghanis; unless specified otherwise) } \\
\hline \multicolumn{7}{|l|}{ General government recurrent budget } \\
\hline Revenues & $\ldots$ & 5,864 & 10,168 & 12,800 & 18,328 & 22,224 \\
\hline Expenditures & $\ldots$ & 15,514 & 22,151 & 26,716 & 32,883 & 38,802 \\
\hline Donor grants and loans & $\ldots$ & 9,430 & 10,074 & 14,984 & 17,643 & 16,578 \\
\hline Revenues (in percent of non-opium GDP) & $\ldots$ & 3.2 & 4.5 & 4.5 & 5.2 & 5.2 \\
\hline Operating expenditures (in percent of non-opium GDP) & $\ldots$ & 8.5 & 9.8 & 9.4 & 9.3 & 9.1 \\
\hline \multicolumn{7}{|c|}{ (In millions of U.S. dollars; unless specified otherwise) } \\
\hline \multicolumn{7}{|l|}{ Monetary indicators } \\
\hline Domestic currency in circulation (annual change; in percent) & $\ldots$ & 20.1 & 40.9 & 37.5 & 27.8 & 22.5 \\
\hline Gross foreign exchange reserves & $\ldots$ & 426.1 & 815.9 & $1,261.3$ & $1,691.4$ & $2,035.9$ \\
\hline \multicolumn{7}{|l|}{ External sector } \\
\hline Exports of goods (including reexports) & 708.9 & $1,290.6$ & $1,893.9$ & $1,656.1$ & $1,892.7$ & $1,959.0$ \\
\hline Exports of goods (annual change; in percent) & $\ldots$ & 82.1 & 46.7 & -12.6 & 14.3 & 3.5 \\
\hline Imports of goods & $1,645.0$ & $2,508.2$ & $3,785.9$ & $3,866.9$ & $4,560.0$ & $4,912.5$ \\
\hline Imports of goods (annual change; in percent) & $\ldots$ & 52.5 & 50.9 & 2.1 & 17.9 & 7.7 \\
\hline Imports of oil & ... & $\ldots$ & $\ldots$ & $\ldots$ & $\ldots$ & \\
\hline Current account deficit (excluding grants) & $\ldots$ & $-1,363.7$ & $-2,334.7$ & $-2,687.5$ & $-3,196.1$ & $-3,414.7$ \\
\hline Current account deficit (including grants; in percent of GDP) & $\ldots$ & -3.5 & 3.1 & 0.7 & 0.5 & -0.8 \\
\hline Afghani/U.S. dollar (average) & 54.4 & 44.8 & 49.0 & 47.7 & $\ldots$ & $\ldots$ \\
\hline \multirow[t]{2}{*}{ Afghani/U.S. dollar (end-year) } & 31.0 & 52.6 & 50.3 & 48.7 & $\ldots$ & $\ldots$ \\
\hline & \multicolumn{6}{|c|}{ (In percent of GDP) } \\
\hline \multicolumn{7}{|l|}{ Investment and savings } \\
\hline Gross investment & $\ldots$ & 28.3 & 35.2 & 38.8 & 40.6 & 36.4 \\
\hline Domestic savings & $\ldots$ & -5.1 & -15.7 & -6.2 & -4.2 & -3.5 \\
\hline \multicolumn{7}{|c|}{ II. Social and Demographic Indicators } \\
\hline Area & \multicolumn{6}{|c|}{652,000 square kilometers } \\
\hline Population $(2002 / 03)$ & \multicolumn{6}{|c|}{21.8 million } \\
\hline Life expectancy at birth (2001) & \multicolumn{6}{|l|}{42.8 years } \\
\hline Infant mortality per 1,000 live births (2003) & \multicolumn{6}{|l|}{115} \\
\hline Under-five mortality per 1,000 live births (2003) & \multicolumn{6}{|l|}{172} \\
\hline
\end{tabular}

Sources: Afghan authorities; and Fund staff estimates and projections.

1/ The fiscal year 2005/06 runs from March 21, 2005 until March 20, 2006. 


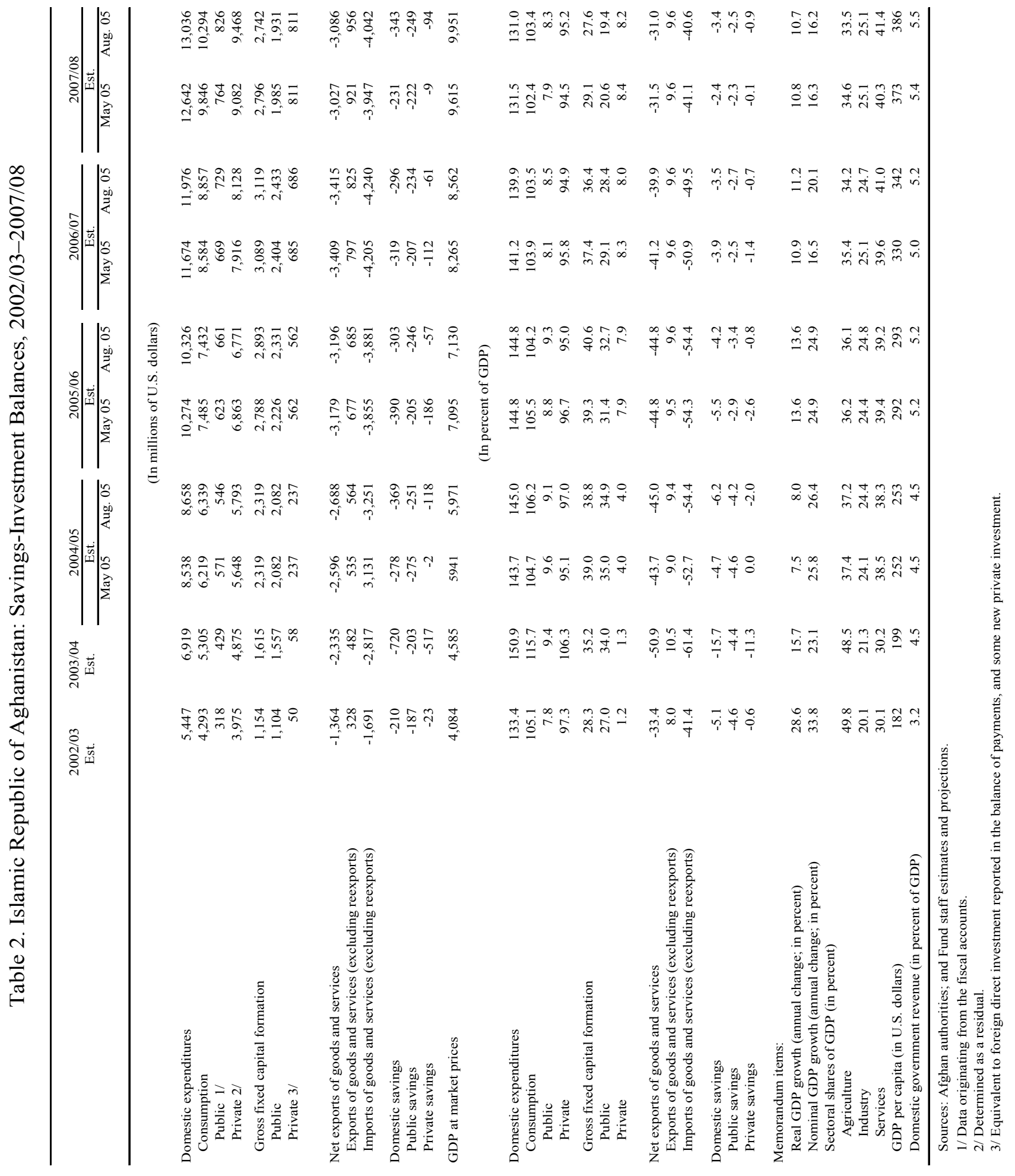


Table 3a. Islamic Republic of Afghanistan: Core Budget, 2002/03-2006/07

\begin{tabular}{|c|c|c|c|c|c|c|c|c|c|c|c|c|}
\hline & \multirow{3}{*}{$\begin{array}{c}2002 / 03 \\
\text { Est. }\end{array}$} & \multirow{3}{*}{$\begin{array}{c}2003 / 04 \\
\text { Est. }\end{array}$} & \multirow{3}{*}{$\begin{array}{c}2004 / 05 \\
\text { Core } \\
\text { Budget } 1 / \\
\end{array}$} & \multicolumn{4}{|c|}{$2004 / 05$} & \multirow{3}{*}{$\begin{array}{c}2004 / 05 \\
\text { Est. } \\
\end{array}$} & \multirow{3}{*}{$\begin{array}{c}2005 / 06 \\
\text { Core } \\
\text { Budget 2/ } \\
\end{array}$} & \multirow{3}{*}{$\begin{array}{c}2005 / 06 \\
\text { Q1 } \\
\text { Est. } \\
\end{array}$} & \multirow{3}{*}{$\begin{array}{l}\text { 2005/06 } \\
\text { Proj. 3/ } \\
\end{array}$} & \multirow{3}{*}{$\begin{array}{r}\text { 2006/07 } \\
\text { Proj. 3/ } \\
\end{array}$} \\
\hline & & & & \multirow{2}{*}{$\begin{array}{l}\text { Q1 } \\
\text { Est. }\end{array}$} & \multirow{2}{*}{$\begin{array}{l}\text { Q2 } \\
\text { Est. } \\
\end{array}$} & \multirow{2}{*}{$\begin{array}{l}\text { Q3 } \\
\text { Est. }\end{array}$} & \multirow{2}{*}{$\begin{array}{c}\text { Q4 } \\
\text { Est. } \\
\end{array}$} & & & & & \\
\hline & & & & & & & & & & & & \\
\hline & & & & & & (In mill & of Afghan & & & & & \\
\hline Domestic Revenue & 5,864 & 10,168 & 15,380 & 2,689 & 3,258 & 2,980 & 3,873 & 12,800 & 16,150 & 4,757 & 18,328 & 22,224 \\
\hline Tax Revenues & --. & 6,262 & 8,886 & 1,993 & 2,495 & 2,201 & 2,857 & 9,546 & 12,274 & 2,681 & 12,250 & 17,143 \\
\hline Taxes on income, profits and capital gains & --- & 363 & 1,276 & 184 & 360 & 205 & 246 & 995 & 1,454 & 158 & 1,923 & 3,610 \\
\hline Taxes on international trade and transactions & -- & 5,369 & 6,039 & 1,600 & 1,654 & 1,708 & 2,285 & 7,247 & 9,044 & 2,238 & 8,206 & 10,752 \\
\hline Other taxes & -- & 531 & 1,571 & 209 & 482 & 287 & 326 & 1,304 & 1,777 & 285 & 2,122 & 2,781 \\
\hline Non Tax Revenues & --- & 3,906 & 6,341 & 696 & 763 & 779 & 1,016 & 3,254 & 3,715 & 2,076 & 6,078 & 5,081 \\
\hline Donor Assistance Grants (to operating budget) & 9,430 & 10,074 & 14,952 & 2,137 & 1,721 & 5,429 & 5,697 & 14,984 & 16,733 & 1,819 & 17,643 & 16,578 \\
\hline ARTF & -- & 8,182 & 12,575 & 2,137 & 1,234 & 4,143 & 4,804 & 12,319 & 13,580 & 1,819 & 13,955 & 13,338 \\
\hline LOTFA and Army Trust Fund & -- & 1,892 & 2,377 & 0 & 404 & 1,286 & 893 & 2,583 & 3,152 & 0 & 3,240 & 3,240 \\
\hline Other grants & -- & 0 & 0 & 0 & 83 & 0 & 0 & 83 & 1 & 0 & 449 & 0 \\
\hline Donor Assistance Grants (core development budget) & -- & 4,569 & 36,882 & 856 & 1,976 & 1,894 & 3,525 & 8,250 & 34,648 & 4,194 & 18,351 & 18,393 \\
\hline Total Core budget expenditure & 15,514 & 31,606 & 67,214 & 6,073 & 9,426 & 11,066 & 12,984 & 39,550 & 91,417 & 10,400 & 56,447 & 63,427 \\
\hline Operating Expenditure & 15,514 & 22,151 & 30,332 & 5,225 & 6,794 & 6,186 & 8,511 & 26,716 & 32,883 & 6,627 & 32,883 & 38,802 \\
\hline Wages and Salaries & --- & 14,660 & 20,813 & 3,411 & 4,834 & 4,801 & 5,855 & 18,902 & 20,239 & 4,031 & 22,263 & 24,572 \\
\hline Purchase of goods and services & --- & 4,653 & 4,862 & 1,052 & 1,012 & 672 & 1,447 & 4,182 & 6,908 & 1,380 & 4,884 & 5,373 \\
\hline Transfers and Subsidies & --- & 652 & 1,471 & 141 & 172 & 238 & 212 & 764 & 1,975 & 371 & 1,975 & 2,272 \\
\hline Pensions & --- & 177 & 724 & 223 & 246 & 227 & 193 & 889 & 1,459 & 782 & 1,459 & 1,678 \\
\hline Capital expenditure & --- & 2,009 & 2,461 & 399 & 529 & 248 & 803 & 1,979 & 2,301 & 63 & 2,301 & 4,907 \\
\hline Interest & & & & & & & & & & 0 & & \\
\hline Core budget development spending 4 / & --- & 9,455 & 36,882 & 849 & 2,632 & 4,880 & 4,474 & 12,834 & 58,534 & 3,773 & 23,564 & 24,625 \\
\hline National programs & --- & 3,339 & 11,817 & 706 & 2,519 & 4,626 & 4,219 & 12,070 & 52,257 & 3,498 & 20,809 & 20,849 \\
\hline 1.4 Livelihoods and Social Protection & -- & 159 & 967 & 105 & 74 & 188 & 194 & 560 & 12,545 & 1,995 & 5,018 & 5,018 \\
\hline 1.5 Culture, Media, Sport & -- & 0 & 0 & 0 & 0 & 0 & 0 & 0 & 467 & 1 & 93 & 0 \\
\hline 2.1 Transport & -- & 75 & 75 & 404 & 254 & 746 & 768 & 2,173 & 12,198 & 808 & 4,879 & 4,891 \\
\hline 2.2 Energy, Mining, and Telecommunications & --- & 852 & 4,560 & 107 & 151 & 332 & 342 & 932 & 11,997 & 282 & 4,799 & 7,140 \\
\hline 2.3 Natural Resources Management & --- & 449 & 1,027 & 0 & 1,987 & 1,292 & 1,330 & 4,609 & 554 & 0 & 222 & 1,651 \\
\hline 2.4 Urban Management & --- & 394 & 1,146 & 0 & 0 & 0 & 0 & 0 & 2,035 & 250 & 814 & 1,128 \\
\hline 3.1 Trade and Investment & --- & 95 & 1,241 & 0 & 0 & 0 & 0 & 0 & 1,343 & 1 & 537 & 255 \\
\hline 3.2 Public Administration Reform and Economic Mana; & --- & 598 & 1,605 & 88 & -42 & 8 & 8 & 61 & 6,368 & 54 & 2,547 & 766 \\
\hline 3.3 Justice & -- & 0 & 0 & 0 & 80 & 1,501 & 1,000 & 2,581 & 151 & 2 & 61 & 0 \\
\hline 3.4 National Police, Law Enforcement and Stabilisation & --- & 319 & 1,196 & 2 & 14 & 560 & 577 & 1,153 & 4,597 & 105 & 1,839 & 0 \\
\hline 3.5 Afghan National Army & -- & 399 & 0 & 0 & 0 & 0 & 0 & 0 & 0 & 0 & 0 & 0 \\
\hline National Priority Programs & --- & 6,115 & 25,065 & 142 & 113 & 254 & 255 & 765 & 6,277 & 275 & 2,755 & 3,777 \\
\hline Education and Vocational Training & --- & 289 & 1,186 & 0 & 47 & 62 & 64 & 172 & 2,318 & 87 & 927 & 760 \\
\hline Health and Nutrition & --- & 508 & 1,111 & 142 & 67 & 183 & 188 & 579 & 1,519 & 188 & 608 & 1,919 \\
\hline National Emergency Employment Program & --- & 2,622 & 2,103 & 0 & 0 & 0 & 0 & 0 & 0 & 0 & 0 & 0 \\
\hline National Solidarity Program & --- & 927 & 6,998 & 0 & 0 & 0 & 0 & 0 & 0 & 0 & 0 & 0 \\
\hline Afghanistan Stabilization Program & --- & 10 & 3,758 & 0 & 0 & 0 & 0 & 0 & 0 & 0 & 0 & 0 \\
\hline National Transportation Program & -- & 1,410 & 8,637 & 0 & 0 & 0 & 0 & 0 & 0 & 0 & 0 & 0 \\
\hline National Irrigation Program & -- & 349 & 1,271 & 0 & 0 & 0 & 0 & 0 & 0 & 0 & 0 & 0 \\
\hline National Feasibility Studies Program & --- & 0 & 0 & 0 & 0 & 0 & 0 & 0 & 0 & 0 & 0 & 0 \\
\hline Other programs & --- & 0 & 0 & 0 & 0 & 10 & 3 & 13 & 2,440 & 0 & 1,220 & 1,098 \\
\hline Operating budget balance (excluding grants) & $-9,650$ & $-11,983$ & 14,952 & $-2,536$ & $-3,536$ & $-3,206$ & $-4,638$ & $-13,916$ & $-16,733$ & $-1,870$ & $-14,555$ & $-16,578$ \\
\hline Operating budget balance (including grants) & -219 & $-1,910$ & 0 & -399 & $-1,815$ & 2,222 & 1,060 & 1,068 & 0 & -51 & 3,089 & 0 \\
\hline Core budget balance & -219 & $-6,795$ & 0 & -392 & $-2,471$ & -764 & 111 & $-3,516$ & $-23,885$ & 370 & $-2,124$ & $-6,232$ \\
\hline Float and adjustment 5/ & -657 & 1,693 & 0 & 1,530 & -609 & 3,140 & $-3,704$ & 357 & 0 & -241 & 0 & $\overline{0}$ \\
\hline Financing & 876 & 5,102 & 0 & $-1,138$ & 3,080 & $-2,376$ & 3,593 & 3,158 & 23,885 & -129 & 2,124 & 6,232 \\
\hline External Loans (net) & & 4,886 & 0 & 2,351 & 6,985 & 1,894 & 3,525 & 14,754 & 23,853 & 0 & 8,219 & 8,722 \\
\hline Domestic (net) & 876 & 217 & 0 & $-3,489$ & $-3,905$ & $-4,270$ & 68 & $-11,596$ & 32 & -129 & $-6,095$ & $-2,490$ \\
\hline Of which: & & & & & & & & & & & & \\
\hline Change in foreign currency deposits $6 /$ & --- & 396 & 0 & $-4,404$ & $-4,508$ & $-3,248$ & 1,703 & $-10,457$ & 0 & -948 & -5718 & $-2,490$ \\
\hline Change on domestic currency deposits 6 / & -502 & -179 & 0 & 915 & 603 & $-1,022$ & $-1,635$ & $-1,139$ & 32 & 819 & -377 & 0 \\
\hline Other financing $7 /$ & 1,379 & 0 & 0 & 0 & 0 & 0 & 0 & 0 & 0 & 0 & 0 & 0 \\
\hline Memorandum item: & & & & & & & & & & & & \\
\hline External budget expenditure & -- & 74,528 & 178,512 & --- & --- & -- & --- & 100,225 & 158,396 & n.a. & 102,958 & 104,679 \\
\hline
\end{tabular}

Sources: Ministry of Finance and Da Afghanistan Bank (DAB); and Fund staff estimates and projections.

1/ Core Budget estimates

2/ June 2005 Supplementary budget, which increased the size of the development budget.

3/ Staff projections.

4/ Government program classification.

5/ Variation between the fiscal position recorded at Ministry of Finance and DAB. This discrepancy is partially due to the difference ("float") between checks issued and checks cashed.

6/ Net transfers from government deposits with DAB. A positive sign corresponds to a decline in balances and a negative sign to an increase in balances.

7/ In 2002/03, includes one-off transfers of overflight revenue and customs valuation fees accumulated over several years and the sale of telecommunication licenses. 
Table 3b. Islamic Republic of Afghanistan: Core Budget, 2002/03-2006/07

\begin{tabular}{|c|c|c|c|c|c|c|c|c|c|c|c|c|}
\hline & \multirow{2}{*}{$2002 / 03$} & \multirow{2}{*}{$2003 / 04$} & \multirow{2}{*}{$\begin{array}{c}2004 / 05 \\
\text { Core } \\
\text { Budget 1/ }\end{array}$} & \multicolumn{4}{|c|}{$2004 / 05$} & \multirow[t]{2}{*}{$2004 / 05$} & \multirow{2}{*}{$\begin{array}{c}2005 / 06 \\
\text { Core } \\
\text { Budget 2/ } \\
\end{array}$} & \multirow{2}{*}{$\begin{array}{c}\text { 2005/06 } \\
\text { Q1 } \\
\text { Est. }\end{array}$} & \multirow{2}{*}{$\begin{array}{l}2005 / 06 \\
\text { Proj. 3/ } \\
\end{array}$} & \multirow{2}{*}{$\begin{array}{r}\text { 2006/07 } \\
\text { Proj. 3/ } \\
\end{array}$} \\
\hline & & & & $\begin{array}{l}\text { Q1 } \\
\text { Est. }\end{array}$ & $\begin{array}{l}\text { Q2 } \\
\text { Est. }\end{array}$ & $\begin{array}{l}\text { Q3 } \\
\text { Est. }\end{array}$ & $\begin{array}{l}\text { Q4 } \\
\text { Est. }\end{array}$ & & & & & \\
\hline & & & & & & (In perc & of GDP) & & & & & \\
\hline Domestic Revenue & 3.2 & 4.5 & 5.4 & 0.9 & 1.2 & 1.1 & 1.4 & 4.5 & 4.6 & 1.4 & 5.2 & 5.2 \\
\hline Tax Revenues & -- & 2.8 & 3.1 & 0.7 & 0.9 & 0.8 & 1.0 & 3.4 & 3.5 & 0.8 & 3.5 & 4.0 \\
\hline Taxes on income, profits and capital gains & --- & 0.2 & 0.5 & 0.1 & 0.1 & 0.1 & 0.1 & 0.4 & 0.4 & 0.0 & 0.5 & 0.8 \\
\hline Taxes on international trade and transactions & -- & 2.4 & 2.1 & 0.6 & 0.6 & 0.6 & 0.8 & 2.6 & 2.6 & 0.6 & 2.3 & 2.5 \\
\hline Other taxes & -- & 0.2 & 0.6 & 0.1 & 0.2 & 0.1 & 0.1 & 0.5 & 0.5 & 0.1 & 0.6 & 0.7 \\
\hline Non Tax Revenues & -- & 1.7 & 2.2 & 0.2 & 0.3 & 0.3 & 0.4 & 1.1 & 1.1 & 0.6 & 1.7 & 1.2 \\
\hline Donor Assistance Grants (to operating budget) & 5.2 & 4.5 & 5.3 & 0.8 & 0.6 & 1.9 & 2.0 & 5.3 & 4.8 & 0.5 & 5.0 & 3.9 \\
\hline ARTF & --- & 3.6 & 4.4 & 0.8 & 0.4 & 1.5 & 1.7 & 4.3 & 3.9 & 0.5 & 4.0 & 3.1 \\
\hline LOTFA and Army Trust Fund & --- & 0.8 & 0.8 & 0.0 & 0.1 & 0.5 & 0.3 & 0.9 & 0.9 & 0.0 & 0.9 & 0.8 \\
\hline Other grants & -- & 0.0 & 0.0 & 0.0 & 0.0 & 0.0 & 0.0 & 0.0 & 0.0 & 0.0 & 0.1 & 0.0 \\
\hline Donor Assistance Grants (core development budget) & -- & 2.0 & 13.0 & 0.3 & 0.7 & 0.7 & 1.2 & 2.9 & 9.8 & 1.2 & 5.2 & 4.3 \\
\hline Total Core budget expenditure & 8.5 & 14.0 & 23.7 & 2.1 & 3.3 & 3.9 & 4.6 & 14.0 & 26.0 & 3.0 & 16.0 & 14.9 \\
\hline Operating Expenditure & 8.5 & 9.8 & 10.7 & 1.8 & 2.4 & 2.2 & 3.0 & 9.4 & 9.3 & 1.9 & 9.3 & 9.1 \\
\hline Wages and Salaries & -- & 6.5 & 7.3 & 1.2 & 1.7 & 1.7 & 2.1 & 6.7 & 5.8 & 1.1 & 6.3 & 5.8 \\
\hline Purchase of goods and services & -- & 2.1 & 1.7 & 0.4 & 0.4 & 0.2 & 0.5 & 1.5 & 2.0 & 0.4 & 1.4 & 1.3 \\
\hline Transfers and Subsidies & --- & 0.3 & 0.5 & 0.0 & 0.1 & 0.1 & 0.1 & 0.3 & 0.6 & 0.1 & 0.6 & 0.5 \\
\hline Pensions & -- & 0.1 & 0.3 & 0.1 & 0.1 & 0.1 & 0.1 & 0.3 & 0.4 & 0.2 & 0.4 & 0.4 \\
\hline Capital expenditure & -- & 0.9 & 0.9 & 0.1 & 0.2 & 0.1 & 0.3 & 0.7 & 0.7 & 0.0 & 0.7 & 1.2 \\
\hline Core budget development spending 4/ & -- & 4.2 & 13.0 & 0.3 & 0.9 & 1.7 & 1.6 & 4.5 & 16.6 & 1.1 & 6.7 & 5.8 \\
\hline National programs & -- & 1.5 & 4.2 & 0.2 & 0.9 & 1.6 & 1.5 & 4.3 & 14.9 & 1.0 & 5.9 & 4.9 \\
\hline 1.4 Livelihoods and Social Protection & -- & 0.1 & 0.3 & 0.0 & 0.0 & 0.1 & 0.1 & 0.2 & 3.6 & 0.6 & 1.4 & 1.2 \\
\hline 1.5 Culture, Media, Sport & -- & 0.0 & 0.0 & 0.0 & 0.0 & 0.0 & 0.0 & 0.0 & 0.1 & 0.0 & 0.0 & 0.0 \\
\hline 2.1 Transport & -- & 0.0 & 0.0 & 0.1 & 0.1 & 0.3 & 0.3 & 0.8 & 3.5 & 0.2 & 1.4 & 1.1 \\
\hline 2.2 Energy, Mining, and Telecommunications & -- & 0.4 & 1.6 & 0.0 & 0.1 & 0.1 & 0.1 & 0.3 & 3.4 & 0.1 & 1.4 & 1.7 \\
\hline 2.3 Natural Resources Management & --- & 0.2 & 0.4 & 0.0 & 0.7 & 0.5 & 0.5 & 1.6 & 0.2 & 0.0 & 0.1 & 0.4 \\
\hline 2.4 Urban Management & --- & 0.2 & 0.4 & 0.0 & 0.0 & 0.0 & 0.0 & 0.0 & 0.6 & 0.1 & 0.2 & 0.3 \\
\hline 3.1 Trade and Investment & -- & 0.0 & 0.4 & 0.0 & 0.0 & 0.0 & 0.0 & 0.0 & 0.4 & 0.0 & 0.2 & 0.1 \\
\hline 3.2 Public Administration Reform and Economic Mana & -- & 0.3 & 0.6 & 0.0 & 0.0 & 0.0 & 0.0 & 0.0 & 1.8 & 0.0 & 0.7 & 0.2 \\
\hline 3.3 Justice & -- & 0.0 & 0.0 & 0.0 & 0.0 & 0.5 & 0.4 & 0.9 & 0.0 & 0.0 & 0.0 & 0.0 \\
\hline 3.4 National Police, Law Enforcement and Stabilisation & -- & 0.1 & 0.4 & 0.0 & 0.0 & 0.2 & 0.2 & 0.4 & 1.3 & 0.0 & 0.5 & 0.0 \\
\hline 3.5 Afghan National Army & -- & 0.2 & 0.0 & 0.0 & 0.0 & 0.0 & 0.0 & 0.0 & 0.0 & 0.0 & 0.0 & 0.0 \\
\hline 3.6 Mine Action & --- & 0.0 & 0.0 & 0.0 & 0.0 & 0.0 & 0.0 & 0.0 & 0.0 & 0.0 & 0.0 & 0.0 \\
\hline National Priority Programs & -- & 2.7 & 8.8 & 0.1 & 0.0 & 0.1 & 0.1 & 0.3 & 1.8 & 0.1 & 0.8 & 0.9 \\
\hline Education and Vocational Training & --- & 0.1 & 0.4 & 0.0 & 0.0 & 0.0 & 0.0 & 0.1 & 0.7 & 0.0 & 0.3 & 0.2 \\
\hline Health and Nutrition & -- & 0.2 & 0.4 & 0.1 & 0.0 & 0.1 & 0.1 & 0.2 & 0.4 & 0.1 & 0.2 & 0.5 \\
\hline National Emergency Employment Program & -- & 1.2 & 0.7 & 0.0 & 0.0 & 0.0 & 0.0 & 0.0 & 0.0 & 0.0 & 0.0 & 0.0 \\
\hline National Solidarity Program & --- & 0.4 & 2.5 & 0.0 & 0.0 & 0.0 & 0.0 & 0.0 & 0.0 & 0.0 & 0.0 & 0.0 \\
\hline Afghanistan Stabilization Program & -- & 0.0 & 1.3 & 0.0 & 0.0 & 0.0 & 0.0 & 0.0 & 0.0 & 0.0 & 0.0 & 0.0 \\
\hline National Transportation Program & --- & 0.6 & 3.0 & 0.0 & 0.0 & 0.0 & 0.0 & 0.0 & 0.0 & 0.0 & 0.0 & 0.0 \\
\hline National Irrigation Program & -- & 0.2 & 0.4 & 0.0 & 0.0 & 0.0 & 0.0 & 0.0 & 0.0 & 0.0 & 0.0 & 0.0 \\
\hline National Feasibility Studies Program & -- & 0.0 & 0.0 & 0.0 & 0.0 & 0.0 & 0.0 & 0.0 & 0.0 & 0.0 & 0.0 & 0.0 \\
\hline Unclassified & -- & 0.0 & 0.0 & 0.0 & 0.0 & 0.0 & 0.0 & 0.0 & 0.7 & 0.0 & 0.3 & 0.3 \\
\hline Operating budget balance (excluding grants) & -5.3 & -5.3 & 5.3 & -0.9 & -1.2 & -1.1 & -1.6 & -4.9 & -4.8 & -0.5 & -4.1 & -3.9 \\
\hline Operating budget balance (including grants) & -0.1 & -0.8 & 0.0 & -0.1 & -0.6 & 0.8 & 0.4 & 0.4 & 0.0 & 0.0 & 0.9 & 0.0 \\
\hline Core budget balance & -0.1 & -3.0 & 0.0 & -0.1 & -0.9 & -0.3 & 0.0 & -1.2 & -6.8 & 0.1 & -0.6 & -1.5 \\
\hline Float and adjustment 5/ & -0.4 & 0.8 & 0.0 & 0.5 & -0.2 & 1.1 & -1.3 & 0.1 & 0.0 & -0.1 & 0.0 & 0.0 \\
\hline Financing & 0.5 & 2.3 & 0.0 & -0.4 & 1.1 & -0.8 & 1.3 & 1.1 & 6.8 & 0.0 & 0.6 & 1.5 \\
\hline External Loans (net) & 0.0 & 2.2 & 0.0 & 0.8 & 2.5 & 0.7 & 1.2 & 5.2 & 6.8 & 0.0 & 2.3 & 2.1 \\
\hline Domestic (net) & 0.5 & 0.1 & 0.0 & -1.2 & -1.4 & -1.5 & 0.0 & -4.1 & 0.0 & 0.0 & -1.7 & -0.6 \\
\hline Of which: & & & & & & & & & & & & \\
\hline Change in foreign currency deposits $6 /$ & --- & 0.2 & 0.0 & 0.3 & 0.2 & -0.4 & -0.6 & -0.4 & 0.0 & -0.3 & -0.1 & -0.6 \\
\hline $\begin{array}{l}\text { Change on domestic currency deposits } 6 \text { / } \\
\text { Other financing } 7 /\end{array}$ & $\begin{array}{r}-0.3 \\
0.8\end{array}$ & $\begin{array}{r}-0.1 \\
0.0\end{array}$ & $\begin{array}{l}0.0 \\
0.0\end{array}$ & $\begin{array}{r}-1.6 \\
0.0\end{array}$ & $\begin{array}{r}-1.6 \\
0.0\end{array}$ & $\begin{array}{r}-1.1 \\
0.0\end{array}$ & 0.6 & $\begin{array}{r}-3.7 \\
0.0\end{array}$ & $\begin{array}{l}0.0 \\
0.0\end{array}$ & $\begin{array}{l}0.2 \\
0.0\end{array}$ & $\begin{array}{r}-0.1 \\
0.0\end{array}$ & $\begin{array}{l}0.0 \\
0.0\end{array}$ \\
\hline Memorandum item: & & & & & & & & & & & & \\
\hline External budget expenditure & -- & 33.1 & 63.0 & --- & --- & --- & --- & 35.4 & 45.0 & n.a. & 29.3 & 24.6 \\
\hline
\end{tabular}

Sources: Ministry of Finance and Da Afghanistan Bank (DAB); and Fund staff estimates and projections.

1/ Core Budget estimates.

2/ June 2005 Supplementary budget, which increased the size of the development budget.

3/ Staff projections.

4/ Government program classification.

5/ Variation between the fiscal position recorded at Ministry of Finance and DAB. This discrepancy is partially due to the difference ("float") between checks issued and checks cashed.

6/ Net transfers from government deposits with DAB. A positive sign corresponds to a decline in balances and a negative sign to an increase in balances.

7/ In 2002/03, includes one-off transfers of overflight revenue and customs valuation fees accumulated over several years and the sale of telecommunication licenses. 


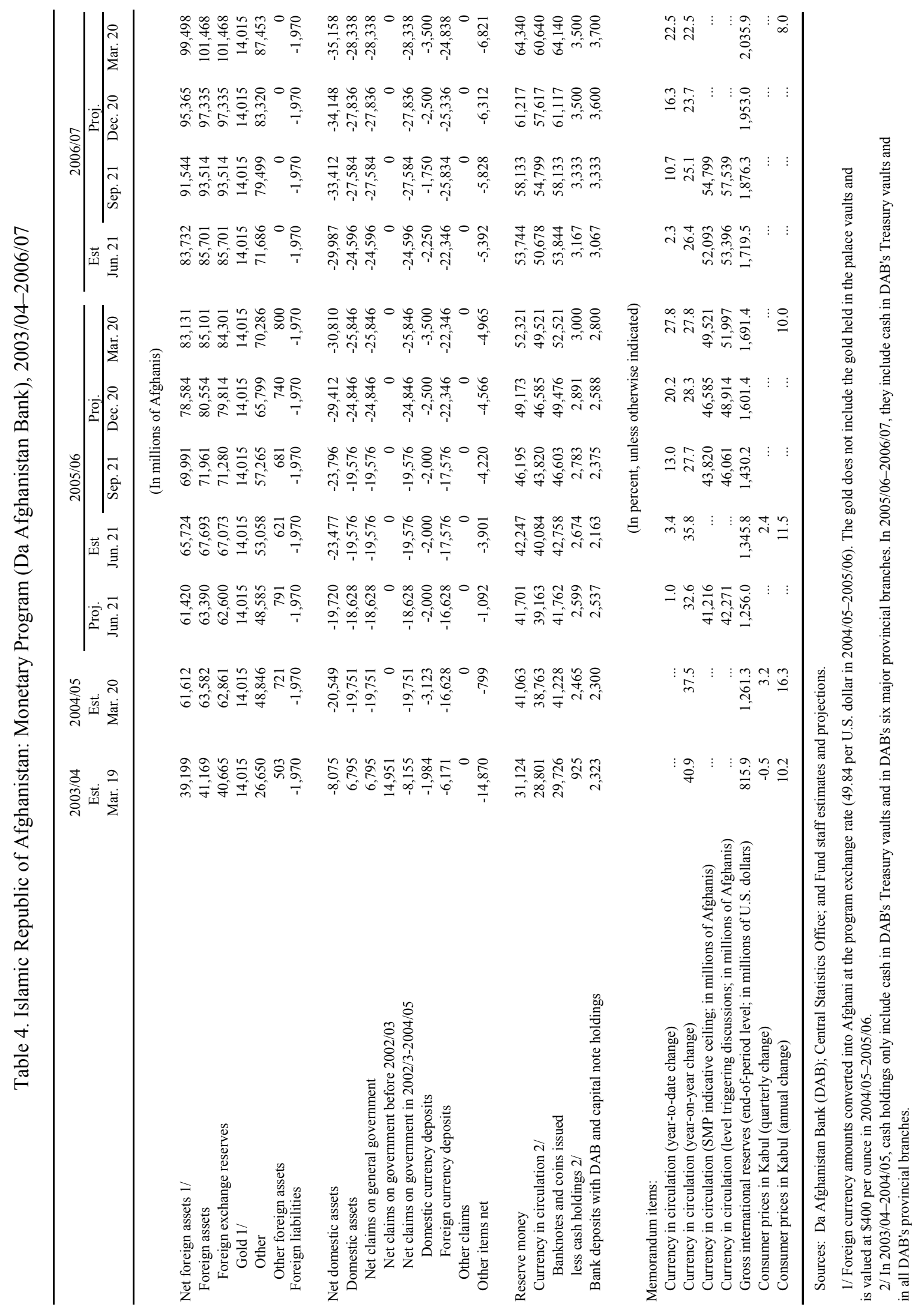


Table 5. Islamic Republic of Afghanistan: Balance of Payments, 2002/03-2007/08

\begin{tabular}{|c|c|c|c|c|c|c|}
\hline & $\begin{array}{c}\text { 2002/03 } \\
\text { Est. }\end{array}$ & $\begin{array}{c}\text { 2003/04 } \\
\text { Est. }\end{array}$ & $\begin{array}{c}\text { 2004/05 } \\
\text { Est. }\end{array}$ & $\begin{array}{c}\text { 2005/06 } \\
\text { Proj. }\end{array}$ & $\begin{array}{c}\text { 2006/07 } \\
\text { Proj. }\end{array}$ & $\begin{array}{c}\text { 2007/08 } \\
\text { Proj. }\end{array}$ \\
\hline & \multicolumn{6}{|c|}{ (In millions of U.S. dollars) } \\
\hline Trade balance & $-1,217.6$ & $-1,892.0$ & $-2,210.8$ & $-2,667.3$ & $-2,953.5$ & $-2,716.3$ \\
\hline Exports of goods 1/ & $1,290.6$ & $1,893.9$ & $1,656.1$ & $1,892.7$ & $1,959.0$ & $1,746.9$ \\
\hline Domestic exports & 276.8 & 376.8 & 471.0 & 564.7 & 678.2 & 793.7 \\
\hline Reexports & $1,013.9$ & $1,517.1$ & $1,185.1$ & $1,328.0$ & $1,280.8$ & 953.2 \\
\hline Imports of goods & $2,508.2$ & $3,785.9$ & $3,866.9$ & $4,560.0$ & $4,912.5$ & $4,463.2$ \\
\hline Recorded imports & $1,142.3$ & $1,688.5$ & $1,993.1$ & $2,481.3$ & $2,913.9$ & $2,886.6$ \\
\hline Duty Free & 840.0 & $1,000.0$ & $1,203.3$ & $1,348.0$ & $1,323.6$ & $1,061.7$ \\
\hline Of which: Commodity food aid & 94.0 & 40.9 & 107.8 & 0.0 & 0.0 & 0.0 \\
\hline Other & 525.9 & $1,097.4$ & 670.5 & 730.8 & 675.0 & 514.9 \\
\hline Services & -145.1 & -439.3 & -480.8 & -542.0 & -480.3 & -392.4 \\
\hline Receipts & 50.8 & 105.5 & 92.5 & 120.5 & 146.9 & 162.6 \\
\hline Payments & 195.9 & 544.8 & 573.3 & 662.5 & 627.2 & 555.0 \\
\hline Income (net) & -1.1 & -3.4 & 4.1 & 13.2 & 19.1 & 23.0 \\
\hline Interest receipts & 0.0 & 4.9 & 13.8 & 25.3 & 32.8 & 38.3 \\
\hline Interest payments $2 /$ & 1.1 & 8.3 & 9.7 & 12.1 & 13.7 & 15.3 \\
\hline Current transfers & $1,221.8$ & $2,476.7$ & $2,728.8$ & $3,234.4$ & $3,343.3$ & $2,805.4$ \\
\hline Public & $1,170.2$ & $2,421.7$ & $2,418.7$ & $2,891.9$ & $2,999.6$ & $2,328.0$ \\
\hline Commodity food aid & 94.0 & 40.9 & 107.8 & 0.0 & 0.0 & 0.0 \\
\hline Other & $1,076.2$ & $2,380.8$ & $2,310.9$ & $2,891.9$ & $2,999.6$ & $2,328.0$ \\
\hline Private $3 /$ & 51.6 & 55.0 & 310.1 & 342.5 & 343.7 & 477.4 \\
\hline Current account (including grants) & -141.9 & 142.0 & 41.3 & 38.3 & -71.4 & -280.2 \\
\hline Current account (excluding grants) & $-1,363.7$ & $-2,334.7$ & $-2,687.5$ & $-3,196.1$ & $-3,414.7$ & $-3,085.7$ \\
\hline Capital and financial account & 144.0 & 147.7 & 345.6 & 381.1 & 405.0 & 430.2 \\
\hline Capital account & 0.0 & 0.0 & 17.6 & 0.0 & 0.0 & 0.0 \\
\hline Foreign direct investment & 50.0 & 57.8 & 186.9 & 212.3 & 236.2 & 261.4 \\
\hline Other investment & 0.0 & 0.0 & -17.6 & 0.0 & 0.0 & 0.0 \\
\hline Public Loans & 94.0 & 89.9 & 158.7 & 168.8 & 168.8 & 168.8 \\
\hline Disbursement & 100.2 & 96.1 & 164.9 & 175.0 & 175.0 & 175.0 \\
\hline Amortization paid 2/ & 6.2 & 6.2 & 6.2 & 6.2 & 6.2 & 6.2 \\
\hline Net errors and omission & -153.2 & -89.3 & -101.6 & 0.0 & 0.0 & 0.0 \\
\hline Overall balance & 155.3 & 379.0 & 488.5 & 419.4 & 333.6 & 150.0 \\
\hline Financing & -155.3 & -379.0 & -488.5 & -419.4 & -333.6 & -150.0 \\
\hline \multicolumn{7}{|l|}{ Changes in reserve assets } \\
\hline Foreign exchange of the DAB & -101.0 & -389.4 & -499.1 & -430.1 & -344.5 & -161.0 \\
\hline Fund credit (net) & 0.0 & 0.0 & 0.0 & 0.0 & 0.0 & 0.0 \\
\hline Purchases & 0.0 & 0.0 & 0.0 & 0.0 & 0.0 & 0.0 \\
\hline Repurchases & 0.0 & 0.0 & 0.0 & 0.0 & 0.0 & 0.0 \\
\hline Exceptional financing & -54.3 & 10.4 & 10.6 & 10.7 & 10.9 & 11.0 \\
\hline Arrears & -54.3 & 10.4 & 10.6 & 10.7 & 10.9 & 11.0 \\
\hline \multicolumn{7}{|l|}{ Memorandum items: } \\
\hline \multicolumn{7}{|l|}{ Official foreign exchange reserves } \\
\hline In millions of U.S. dollars & 426 & 816 & 1,261 & 1,691 & 2,036 & 2,197 \\
\hline In months of prospective imports 4/ & 1.8 & 3.1 & 3.9 & 4.8 & 5.5 & 6.5 \\
\hline \multicolumn{7}{|c|}{ Current account balance (in percent of GDP) } \\
\hline Including grants & -3.5 & 3.1 & 0.7 & 0.5 & -0.8 & -2.8 \\
\hline Excluding grants & -33.4 & -50.9 & -45.0 & -44.8 & -39.9 & -31.0 \\
\hline GDP (millions of U.S. dollars) & 4,084 & 4,585 & 5,971 & 7,130 & 8,562 & 9,951 \\
\hline
\end{tabular}

Sources: Afghan authorities; and Fund staff estimates and projections.

1/ Excludes opium exports and, because information is unavailable, flows associated with U.S. Army and most ISAF activities.

2/ Debt service projections are based on recognized obligations, reconciled with creditors. Arrears shown here represent an estimate by Fund staff, on the basis of loans which have been verified with creditors, but are not being serviced.

3/ Includes foreign transactions recently reported by licensed money changers

4/ In months of imports of goods and services, excluding imports for reexport. 


\section{Islamic Republic of Afghanistan: Relations with the Fund}

(As of July 31, 2005)

I. Membership Status: Joined July 14, 1955; Article XIV.

$\begin{array}{lrr}\text { II. General Resources Account } & \text { SDR Million } & \text { \% Quota } \\ \text { Quota } & 161.90 & 100.00 \\ \text { Fund holdings of currency } & 161.92 & 100.01 \\ \text { Reserve position in Fund } & 0.00 & 0.00\end{array}$

III. SDR Department

Net cumulative allocation Holdings

IV. Outstanding Purchases and Loans

V. Financial Arrangements

VI. Projected Obligations to Fund

(SDR million; based on existing use of resources and present holdings of SDRs)

$\begin{array}{rr}\text { SDR Million } & \text { \% Allocation } \\ 26.70 & 100.00 \\ 0.18 & 0.67\end{array}$

None

None

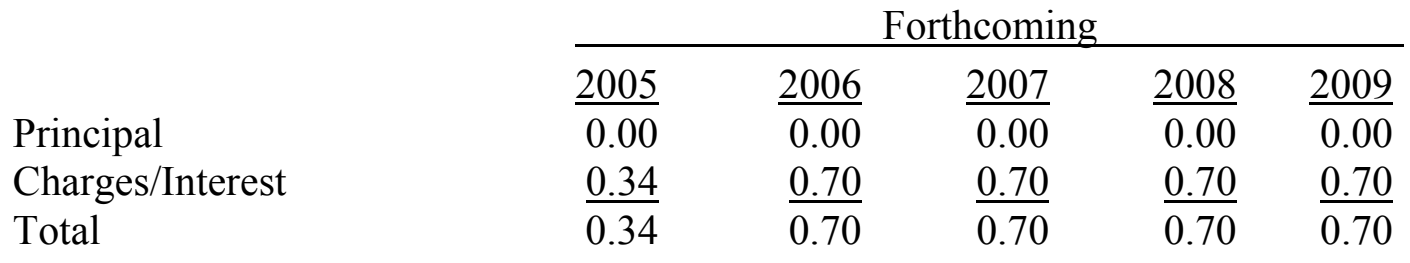

VII. Implementation of HIPC Initiative Not Applicable

\section{Nonfinancial Relations}

\section{Exchange Arrangement}

Afghanistan is an Article XIV member country. The authorities are implementing a liberal exchange system. Based on information currently available to the staff, no exchange restrictions and multiple currency practices are currently in place. The authorities intend to formalize the current liberal regime through the adoption of new laws and regulations, for which they have asked for technical assistance from the Fund. A joint LEG/MFD mission is envisaged to take place over the next few weeks. At least since end-2001, the Afghani has been floating, and more recently the authorities have been implementing a managed float with no predetermined path for the exchange rate. As of September 7, 2005, the average exchange rate on the Kabul money exchange market was Af 49.28 per $\$ 1$. 
To conduct monetary policy, the authorities rely on foreign exchange auctions since May 2002, and on short-term capital note auctions since September 2004. Initially only open to licensed money changers, the foreign exchange auctions have been open to commercial banks since June 2005. The capital note auctions are open to commercial banks. Auctions are linked to the overall monetary program and are held on a regular basis (weekly for foreign exchange auctions, daily for capital note auctions). Reserve requirements have started to be implemented in May 2005.

\section{Article IV Consultation}

The last Article IV consultation with Afghanistan was discussed by the Executive Board on January 19, 2005. Consultations with Afghanistan are on the standard 12-month cycle.

\section{Technical Assistance, 2004-05}

\begin{tabular}{|c|c|c|}
\hline Department & Date & Purpose \\
\hline \multirow[t]{4}{*}{ FAD } & March 2004 (ongoing) & Resident Treasury Expert \\
\hline & March 22-April 3, 2004 & Tax policy and administration \\
\hline & April 18-May 2, 2004 & Customs administration \\
\hline & May $19-25,2005$ & Seminar of reorganization of the MoF \\
\hline \multirow[t]{5}{*}{ MFD } & February 2-6, 2004 & Anti-money laundering legislation \\
\hline & March 21-30, 2004 & $\begin{array}{l}\text { DAB capital adequacy and balance } \\
\text { sheet structure }\end{array}$ \\
\hline & September 2004 (ongoing) & Training coordinator \\
\hline & February $2-15,2005$ & $\begin{array}{l}\text { Implementation of DAB balance sheet } \\
\text { reconstruction and capital adequacy } \\
\text { recommendations }\end{array}$ \\
\hline & May 16-25, 2005 & Monetary Policy and Financial Markets \\
\hline \multirow[t]{3}{*}{ LEG } & February 2-6, 2004 & Anti-money laundering legislation \\
\hline & March 3-21, 2004 & Fiscal revenue legislation \\
\hline & January 29-February 12,2005 & Income Tax Law \\
\hline \multirow[t]{7}{*}{ STA } & January 29-March 15, 2004 & Multisector statistics \\
\hline & April 19-May 3, 2004 & Balance of Payments Statistics \\
\hline & May 13-June 30, 2004 & Multisector statistics \\
\hline & May $17-29,2004$ & Consumer Price Index \\
\hline & January 15-February 15,2005 & Multisector Statistics \\
\hline & March 23-June 11, 2005 & Multisector Statistics \\
\hline & July 20-August 31,2005 & Multisector Statistics \\
\hline MCD & April 16-20, 2005 & $\begin{array}{l}\text { Basic Macroeconomic Accounting } \\
\text { Relationships and Introduction to } \\
\text { Financial Programming }\end{array}$ \\
\hline
\end{tabular}


Afghanistan is a participant in the Middle East Technical Assistance Center (METAC).

A resident treasury expert for the Ministry of Finance, Mr. Platais, has been appointed since March 2004.

A resident multisector statistical advisor, Mr. Soulatha, was stationed in Kabul on July 17, 2002. STA has provided technical assistance through a series of missions under a peripatetic multisector statistics assignment which began in January 2004. These missions were suspended in July 2004 due to the security situation. A new series of peripatetic missions commenced in January/February 2005. Four missions, accounting for a total of nine months of technical assistance, are scheduled to be delivered over a 12-month period. The first three missions took place from January 15-February 15, 2005, from March 23-June 11, 2005, and from July 20-August 31, 2005, respectively.

During 2004, with financial support from the Sweden Technical Assistance SubAccount, the Fund has sponsored a number of training activities aimed at DAB officials and conducted a full-scale training program for DAB. A long-term training advisor, Mr. Khan, was appointed in September 2004. He is responsible for all practical matters related to the delivery of formal training to DAB staff in Kabul, as well as the coordination of training for DAB staff outside Afghanistan. He has already carried out a training needs assessment and finalized a training plan for 2005, which has been approved by both DAB and Sweden and is being implemented. Finally, Sweden has agreed to finance during the period December 2004 to December 2005 a monetary policy peripatetic advisor, Mr. Coats, to assist DAB in developing the strategy and the instruments for the implementation of the next stage of monetary policy — setting and advising on options to replace the existing exchange rate auctions.

\section{Resident Representatives}

During the first half of 2002, the Fund's resident representative in Pakistan, Mr. Ghesquière, assisted in maintaining relations with the Afghan authorities. A resident representative, Mr. de Schaetzen, took up his post in Kabul on August 24, 2002. Mr. Charap succeeded him on June 13, 2005. 


\section{Islamic Republic of Afghanistan: Relations with the World Bank}

(As of September 12, 2005)

1. A second Transitional Support Strategy (TSS) was presented to the World Bank Board of Executive Directors in March 2003. This was due to be updated by March 2005 following the culmination of the political process outlined in the Bonn process. Despite a successful Presidential election in October 2004, parliamentary elections in Afghanistan have been postponed until September 2005. This delay in the political process, coupled with the government's intentions to develop a National Development Strategy in 2005, have delayed the World Bank's efforts to develop a new Interim Strategy Note. The World Bank continues to assist the government operate under the existing TSS and is now making plans to prepare an Interim Strategy Note, in line with the government's plans for the National Development Strategy, in early 2006.

2. In FY 2002, World Bank staff prepared and negotiated four projects to utilize IDA grant funds to a total of $\$ 100$ million. Following the clearance of Afghanistan's arrears to the World Bank and Fund, through donor contributions, the first IDA credit for \$108 million for the Emergency Transport Project was approved by the Board in March 2003. By the end of FY 2003, an additional three projects - Emergency Health Sector Rehabilitation (\$59.6 million), Emergency Public Administration II (\$8.4 million), and National Emergency Employment II (\$39.2 million) were approved bringing to \$215 million the total allocation for the year.

3. Five IDA credits/grants were negotiated for FY 2004, for a total of \$293 million. These programs include the Emergency Communications Project (\$22 million), the Emergency Customs Modernization and Trade Facilitation (\$31 million), the National Solidarity Program II (\$95 million), the Emergency Irrigation Rehabilitation (\$40 million), and the Emergency Power Rehabilitation (\$105 million).

4. For FY 2005, six projects and two supplementals were approved, for a total of \$285 million: the first budget-support operation, Programmatic Support for Institution Building (\$80 million); the Kabul Urban Reconstruction Project (\$25 million); the Investment Guarantee Facility ( $\$ 5$ million), together with MIGA; the Education Quality Improvement Program (\$35 million); Public Administration Capacity Building (\$27 million); Strengthening Higher Education (\$40 million); and supplemental financing for the Emergency Transport Project (\$45 million) and the National Solidarity Program (\$28 million).

5. The World Bank also administers the Afghanistan Reconstruction Trust Fund (ARTF), which became effective in May 2002 and plays a critical role in funding the recurrent costs of government. In its first year of operation (2002/03), the ARTF mobilized $\$ 185$ million and disbursed \$65 million. Paid-in contributions for 2003/04 amounted to \$286 million, while disbursements reached \$254 million. Paid-in contributions for 2004/05 
amounted to $\$ 380$ million, while disbursements reached $\$ 292$ million. Pledges for 2005/06 have reached $\$ 462$ million, with $\$ 154$ million having been paid in (as of August 22, 2005). ARTF is increasing its financing of investments and has the potential to support tighter donor coordination, simplified processes, and fast results.

6. The World Bank is also actively engaged in advisory services to government and continues to respond quickly to a range of requests. Current analytical work includes work on the civil service reform, urban development and land management, education policy reform, labor market and pensions, and oil/gas infrastructure development, as well as broader regional trade work encompassing issues with Afghanistan's neighbors. A Gender Assessment is due to be released publicly shortly. The World Bank has notably initiated a major Public Finance Management (PFM) Review, which incorporates a review of public expenditures and fiduciary aspects, including procurement and financial management. Fund staff are contributing to the PFM review, including through providing an analysis of domestic revenue prospects. The World Bank has also actively utilized Post Conflict Fund and continues to use the Japan Social Development Fund resources to provide on-theground support to the government and communities.

7. The World Bank's program is growing quickly and has an active IDA portfolio of 18 investments as of August 2005 and two supplementals (one project has closed). Total commitments since 2001 add up to $\$ 893$ million, of which $\$ 457$ million in grants. A number of projects are under preparation for FY05 including a second budget support operation. Total commitments for FY 2005 are expected to reach \$267 million, entirely in grants. 
Kabul, September 26, 2005

Mr. Rodrigo de Rato

Managing Director

International Monetary Fund

Washington, DC 20431

U.S.A.

Dear Mr. de Rato,

1. For two weeks starting August 1, 2005, we have carried out discussions with IMF staff on the fifth review under the staff-monitored program (SMP) agreed to in March 2004 and updated on September 6, 2004, December 29, 2004, February 3, 2005, and May 18, 2005, respectively.

2. We would like to report that our program remains on track. We have met all end-June 2005 quantitative targets and structural benchmarks and most of our other commitments under the SMP, as described in the May 18 Memorandum of Economic and Financial Policies (MEFP). Looking forward, we have reached understandings on the policies for 2005/06 and the first half of 2006/07 and on the priorities for the medium term. Our strategy remains focused on creating adequate conditions for sustainable economic growth and reducing poverty in the context of fiscal and external sustainability. The attached update to the MEFP reviews macroeconomic developments and implementation of structural reform measures during the first quarter of 2005/06, and our policy intentions and targets for the remainder of $2005 / 06$.

3. The six-month extension of the SMP agreed on at the time of the third review is to end in September 2005. The SMP has contributed to the good performance of the Afghan economy over the period and the program's main objectives have been successfully achieved. While we are working on our interim national development strategy, we would like to continue with a SMP, which will provide us with a framework for maintaining the current macroeconomic policy stance and ongoing structural reforms. We therefore request an additional 12-month extension of the SMP through September 2006. Accordingly, we have reached understandings with IMF staff on a set of new quantitative targets and structural benchmarks for end-September 2005, end-December 2005, end-March 2006, end-June 2006, and end-September 2006.

4. We believe that the policies and measures set forth in the attached update to the MEFP are adequate to achieve the objectives of the program, but we will take any further measures that may become appropriate for this purpose. The Government of Afghanistan will consult with the IMF prior to adoption of any such measures and of revisions to the policies contained in the MEFP, in accordance with the IMF' s policies on such consultations. We will also provide any information required to assess the implementation of the SMP. 
5. In continuing with our policy of transparency, we consent to the publication of this letter, the attached MEFP, the technical memorandum of understanding, and the accompanying Executive Board documents on the IMF's website.

Sincerely yours,

$/ \mathrm{s} /$

Anwar Ul-Haq Ahady

Minister of Finance

Ministry of Finance /s/

Noorullah Delawari Governor

Da Afghanistan Bank

Attachments:

Update to the Memorandum of Economic and Financial Policies

Technical Memorandum of Understanding 


\title{
Update to the Memorandum of Economic and Financial Policies of the Government of Afghanistan
}

\author{
Fifth Review Under the Staff-Monitored Program and Request \\ for Extension, 2004/05-2006/07
}

August 16, 2005

\section{INTRODUCTION}

1. This update to the Memorandum of Economic and Financial Policies (MEFP) reviews performance during the fifth quarter (April-June 2005) of the Staff-Monitored Program (SMP) and describes policies and targets for the remainder of 2005/06 and the first half of $2006 / 07$. The program will continue to be guided by the macroeconomic and structural reform policies described in the MEFP of March 2004, and in the updates of September 6, 2004, December 29, 2004, February 3, 2005, and May 18, 2005. The sixth review under the SMP is scheduled for early November 2005 and will coincide with the 2005 Article IV discussions. This review, which will take place after the September 18 general elections, will assess performance during the second quarter of 2005/06 (JulySeptember 2005). Key issues will include the findings of the midyear budgetary review (MYR), scheduled for September/October, fiscal and external sustainability, tax and customs reforms, and progress made in bank restructuring.

\section{The SMP has contributed significantly to establishing and then maintaining} macroeconomic stability. It has provided a supportive framework for financial and monetary discipline and helped to improve coordination with the donor community. As we are still preparing our National Development Strategy (NDS), which will form the basis for an interim poverty reduction strategy paper (I-PRSP), we would like to maintain our cooperation with the IMF under the SMP, so as to continue to benefit from IMF staff advice on elaborating the framework for implementing and coordinating macroeconomic policies and structural reforms, and continue to build the capacity to implement a formal arrangement. Accordingly, we request a 12-month extension of the SMP, through end-September 2006. This extension does not preclude moving into a more comprehensive program, such as the PRGF, at some point before the SMP expires, notably once the I-PRSP is finalized.

\section{We have observed all end-June 2005 quantitative targets and structural} benchmarks. Over the next 12 months, we will continue to focus on ensuring macroeconomic stability, strengthening capacity and improving the statistical base. 


\section{DEVELOPMENTS UNDER THE SMP}

4. Macroeconomic developments during the first quarter of $2005 / 06$ were broadly in line with program projections. Real GDP growth for 2004/05 was revised slightly upward, from 7.5 to 8.0 percent, reflecting a more buoyant performance in the manufacturing sector than initially estimated. Economic activity during the first quarter seems to have been consistent with program projections and was led by a rebound in agriculture, as a result of winter and spring precipitation, and by continued strong growth in the manufacturing and service sectors.

5. Year-on-year inflation declined in Kabul during the first quarter of 2005/06, to 11.5 percent at end-June from 16.3 percent at end-2004/05. ${ }^{1}$ This decline reflected essentially a sharp slowdown in rents, which increased by 8.1 percent during the first quarter compared with 41.2 percent a year earlier; the stability of education fees, which had almost doubled during the first quarter of 2004/05; and a slowdown in food prices. Excluding rents and petroleum products prices, year-on-year inflation declined from 11.3 percent at end-2004/05 to 9.0 percent at end-June.

6. Opium production is expected to decline in 2005. The intensification of the government's anti-narcotics efforts and the relatively low farm gate prices contributed to a substantial decline in cultivation. However, this decline is expected to be partly offset by a rebound in yields, which had fallen by 29 percent in 2004 because of bad weather conditions and the prevalence of diseases. Overall, we expect opium production to decline. Farm gate prices remained low during the first quarter of 2005/06, probably on account of large inventories and interdiction.

7. Provisional data indicate that domestic revenues reached Af 4,757 million in the first quarter of 2005/06, slightly above the SMP indicative target (Af 4,629 million). ${ }^{2}$ This outcome represents a significant increase, of over 75 percent, in domestic revenues compared with the same period last year. This was attributable to both an increase in customs revenue, of around 40 percent, and the delayed transfer of about Af 800 million in overflight charges accrued in previous years, which more than compensated for a decline in domestic tax revenues.

\footnotetext{
1 The year-on-year increase in the national CPI, which covers five major cities in addition to Kabul, declined from 11.6 percent to 10.3 percent, primarily due to lower rent increases.

2 The Ministry of Finance has recently introduced new procedures to reconcile the revenue reports and banking data. Over time, this should enhance considerably the integrity of fiscal reporting, although discrepancies remain, which need to be resolved.
} 
8. Improvements in budget preparation helped to limit the payment delays, notably for wages, that had occurred at the start of previous years. Core budget operating spending was Af 6.6 billion during the first quarter, compared with an annual budget estimate of Af 32.9 billion. Wages and salaries contributed around 60 percent of operating expenditures.

9. A supplementary development budget was approved in June to incorporate additional donor-funded projects. Core budget development spending is now budgeted at 16.6 percent of GDP in 2005/06, up from an outturn of 4.5 percent in 2004/05, and a preliminary budget estimate of 13.2 percent of GDP. During the first quarter of 2005/06, it amounted to Af 3.8 billion, compared with an annual budget estimate of Af 58.5 billion. Development spending continues to be hampered by: (i) the lack of capacity in line ministries and implementing agencies to develop and implement projects; (ii) the lead time required to design and initiate projects; and (iii) security concerns. To address these capacity constraints, we are building capacity in the line ministries and have recently created a National Project Support Office in the President's office to help line ministries develop and manage new projects. These initiatives should improve disbursement rates over time, more in line with the ambitious budget targets for development spending.

10. We continue to observe our "no-overdraft" financing commitment as the core budget was funded exclusively by domestic revenues and foreign grants. The external supplementary budget, which is executed directly by donors, remained broadly unchanged, at 45 percent of GDP in 2005/06, compared with estimated spending of 35 percent of GDP in 2004/05. Part of the external budget (equivalent of 21.3 percent of GDP) is unfunded and projects will not commence until the funding is secured.

\section{The promulgation in June of the new Public Financial Management Law, an} end-June benchmark, constitutes a significant step towards a modern fiscal system. The new budget law provides a clear and transparent budget framework, stricter guidelines for budget formulation, execution and financing, and sets out a consistent framework for internal control and internal and external audit. In support of our policy of fiscal transparency, the Ministry of Finance has begun publishing monthly statements of fiscal performance for the core budget and we intend to produce a regular quarterly fiscal bulletin during the year. The Ministry of Finance has approved a plan to integrate the former Accounting Department of the Ministry of Finance in the Treasury, in accordance with the Public Financial Management Law, and some staff have already moved under the Treasury. However, the integration process will not be completed for several months as the restructuring plan has to be submitted to and approved by the Independent Administrative Reform and Civil Service Commission.

\section{Currency in circulation increased by 3.4 percent during the first quarter of} $\mathbf{2 0 0 5 / 0 6}$, to Af 40.1 billion at end-June, significantly below the SMP first quarter ceiling (Af 41.2 billion). Due in part to the government's further accumulation of deposits with $\mathrm{DAB}$, international reserves continued to increase, to $\$ 1.3$ billion (equivalent to 3.8 months of 2006/07 imports). While the interest rate on the overnight capital note remained low, at 
1-2 percent, the rate on the 30-day note increased slightly, fluctuating between 5 and 6 percent during the first quarter. The 30-day note auctions were no longer systematically undersubscribed, due to the participation of some private banks in addition to the two state-owned banks that had previously been the only bidders. The nominal exchange rate depreciated slightly, losing 3 percent against the U.S. dollar during the first quarter of $2005 / 06$. The real exchange rate, which appreciated in 2004/05, remained broadly unchanged as domestic prices increased slightly faster than foreign prices.

13. Further progress was made in modernizing the central bank. We published the financial statements of the 2003/04 external audit of DAB. We also started implementing the recommendations of the recent IMF technical assistance mission on monetary policy and financial markets. In particular, we improved substantially the operating procedures of the foreign exchange auctions by moving to a standard auction system (with confidential bids, no renegotiation, and allowing for multiple bids) and allowing commercial banks to participate along with money-changers. We also strengthened the monetary policy institutional framework by establishing a monetary policy committee in charge of daily operational issues. We initiated the transfer of DAB's commercial activities in its city branches in Kabul and in branches located in provinces where at least one commercial bank operates. Lastly, we conducted, with the help of a local expert, a preliminary assessment of the gold and silver held in the palace vaults.

14. The current account deficit, excluding grants, declined in $2004 / 05$, to 45.0 percent of GDP from 50.9 percent of GDP in $2003 / 04$, due primarily to a slowdown in imports. The deficit continued to be financed essentially by grants, although there has been an increase in foreign direct investment and concessional borrowing. Including grants, the current account recorded a surplus equivalent to 0.7 percent of GDP, compared with 3.1 percent of GDP in 2003/04.

\section{As part of our efforts to improve balance of payments data, we started} implementing the recommendations of the May 2005 IMF STA technical assistance mission. In particular, we harmonized the sources and assumptions on trade flows, and made adjustments to account for illegal trade, private grants, and the international investment position. We are also improving collection of data on the financial accounts through various surveys and questionnaires.

\section{POLICIES FOR THE REMAINDER OF 2005/06 AND 2006/07}

16. With the legislative election fast approaching, security is expected to remain an issue and could, to a certain extent, slow down our reform process and ultimately affect negatively the performance of the Afghan economy. Even if security improves, the establishment of a stable political and legislative environment will take time as the country has not had any recent experience with a Parliament. This could effect donor support and complicate program implementation. Against this background, we intend to build on the first quarter performance, 
which was in line with SMP projections, and continue our efforts to implement prudent economic policies with the aim of maintaining macroeconomic stability and sustaining growth while fighting pervasive poverty.

\section{A. Macroeconomic Objectives}

17. Economic policies for the remainder of 2005/06 and the first half of 2006/07 remain in line with the medium-term objectives of improving growth prospects, facilitating the development of the private sector, and maintaining fiscal and external sustainability. For that purpose, and as indicated in our previous memoranda, increased revenue collection through sustained tax and customs administration reforms will remain a key priority. At the same time, we will improve spending efficiency and prioritization consistent with the NDS and the Millennium Development Goals.

18. Economic developments were broadly in line with the projections made at the time of the fourth review, and growth and price projections remain unchanged. Real GDP is expected to grow by 13.6 percent in 2005/06, reflecting the rebound of agricultural output due to better precipitation, as well as continued growth in construction, transports and telecommunications. In 2006/07, as the economy matures and agricultural growth returns to its trend, economic growth is likely to moderate somewhat, to a projected 11.2 percent. On account of the expected slowdown in rents and food prices and of the tightening of the monetary stance, inflation is expected to decline further, to 10 percent year-on-year at end-2005/06 and 8 percent year-on-year at end 2006/07.

19. To ensure that the decline in opium production observed this year is sustained over the medium term, we will pursue the implementation of our anti-narcotics strategy. The sharp decline in planted areas observed this year in most provinces, which arose from non-planting (i.e. farmers deciding not to plant) and to eradication, has validated our multi-pronged approach combining eradication, interdiction and alternative livelihoods. The persistence of relatively low farm gate prices should help us in pursuing our strategy. Nevertheless, to realize continued success will require major efforts and new initiatives from both our government and our development partners on all fronts. The newly created Ministry of Counter-Narcotics is coordinating the policy efforts in this area.

\section{B. Fiscal Policy}

20. The NDS will help to define national and sectoral policies that are clear, affordable and realistic within a Medium-Term Fiscal Framework (MTFF). The MTFF, an end-December benchmark, will present our policy objectives and a set of integrated macroeconomic and fiscal targets, and assumptions and projections over the next three to five years, including financing requirements. This should allow us to better articulate the path towards fiscal sustainability and to provide a framework that, along with improved fiduciary standards, will encourage donors to channel, with greater predictability, an increasing proportion of their financial assistance through the core budget. The NDS and MTFF can help to improve the realism of the budget processes and outcomes, provide more 
comprehensive coverage and the linking of recurrent and capital costs, enhance the predictability of budget allocations and improve the transparency in the use of resources.

21. The scope for further budgetary adjustments will be considered, in collaboration with our development partners at the time of the MYR, scheduled for

September/October. The MYR process, established in 2004, has significantly improved the quality of budget management by allowing transparent adjustments during the year and creating a link between this year's budget execution and the preparation of the next budget. In order to improve budget execution, in particular for development expenditures, the MYR will identify and implement strategies to accelerate program delivery and to remove or reduce allocations to nonperforming programs. We also anticipate the inclusion of additional donor funds as commitments become firm during the year or projects, such as for the Counter Narcotics Trust Fund, are included in the core budget.

22. We envisage a wage adjustment as part of the MYR, which will be consistent with medium-term fiscal sustainability. Considering the relatively low level of current wage rates, and that no general increases have been awarded since November 2003, a nominal wage increase for non-uniformed public servants is becoming unavoidable. However, domestic revenues cover only about half of the operating budget, and wage-related costs are due to rise considerably over the medium term due to the ongoing public administration reforms and possibly the need to absorb additional security-related costs. To the extent possible, we will restrict any increase in the general pay scales for non uniformed public servants at the time of the MYR to no more than Af 600 million, which should be more than offset by additional domestic revenues. We also realize the importance of carefully quantifying and controlling any pay award and also of discussing these proposals with the main donors who finance a significant share of the budget.

23. The current revenue-to-GDP ratio is one of the lowest in the world and the increase in domestic revenues remains our highest priority. The SMP revenue projection for 2005/06, at 5.2 percent of GDP, is greater than the budget projection, but is achievable in light of the expected receipt of both the 2004/05 and 2005/06 overflight payments in this fiscal year, and provided that customs and tax administration reform programs are well implemented. ${ }^{3}$ The immediate revenue reform effort will focus on strengthening the large tax payer unit, establishing tax enforcement powers by end-September 2005, and improving tax and customs administration and infrastructure. We are also considering the introduction of excise taxes in the near future.

24. The recent legislative changes provide a solid foundation upon which modern tax and customs administrations can be built. We are committed to reducing complexity

${ }^{3}$ The SMP revenue target is Af 18,328 million, compared to a budget target of Af 16,150 million. 
and streamlining procedures, so as to reduce compliance costs, for both tax and customs. New regulations and procedures for customs and tax administration are now required to support the implementation of recently enacted legislation in these areas and to ensure that the government has adequate authority to control and manage public finances. We will conduct a review of the tax structure during the year, in consultation with the private sector, with a view to abolishing the plethora of 'nuisance' taxes and illicit charges. Properly controlling duty and tax exemptions is also critical, particularly given the high value of donor imports that are duty-exempt and the risk that this causes a proliferation of unjustified exemptions and undermines the revenue base. Therefore, we will take steps to strengthen the implementation of our exemption monitoring system.

25. Fiscal reporting and the reconciliation of fiscal and banking data have improved markedly over the last year and we will maintain our efforts in this area. One of the major challenges to improve the domestic revenue administration and the payment and accounting systems is the reform of the provincial treasuries (Mustofiats). New regulations, procedures, systems - based on the new public financial management law - and institutional reforms are required. This includes the reorganization of the Mustofiats along functional lines reporting to the Treasury and General Presidency of Revenue. With the support of donors, we will continue to implement the plan to reform the Mustofiats over the coming year.

\section{Monetary and Exchange Rate Policies}

26. As price, exchange rate, and monetary developments during the first quarter were broadly in line with SMP projections, monetary policy will continue to be guided by the $2005 / 06$ monetary program agreed upon at the time of the third review. The relative slow growth of currency in circulation during the first quarter should provide us with sufficient room to accommodate a potential sharp increase in money demand during the second quarter, similar to those observed in the previous two years. At the same time, the program provides for a further tightening of the monetary stance during the remainder of the year, consistent with DAB's primary objective to bring inflation under 10 percent. The exchange rate will continue to be market-determined. International reserves are expected to increase further, to about $\$ 1.7$ billion at end-2005/06, equivalent to 4.8 months of $2006 / 07$ imports. ${ }^{4}$ The monetary program will remain flexible to account for unanticipated changes in the demand for currency on account of factors such as increased Afghanization or changes in financial sector developments.

\footnotetext{
${ }^{4}$ The quarterly quantitative indicators (floor) for gross international reserves were set so as to be consistent with a minimum coverage of 2006/07 imports of four months at end-2005/06.
} 
27. We continue to modernize DAB's operations. We will restructure further DAB's balance sheet by: finalizing, by end-September 2005, the transfer of DAB's commercial accounts in its city branches in Kabul and in its branches located in provinces where at least one fully-licensed commercial bank operates; and processing the gold held in the palace vaults into a form that qualifies as a reserve asset, and transferring, by end-September 2006, any monetary gold held in Afghanistan to an international gold center. To address more effectively commercial banks' liquidity needs, we will introduce by end-December 2005, with technical assistance from the IMF, an overnight collateralized credit facility against capital notes and allow participants in the foreign currency auctions to sell, as well as to buy, U.S. dollars. If the demand for capital notes, notably from the private banks, continues to increase, we are considering introducing longer-maturity notes. Lastly, consistent with our commitment to transparency, by end-December 2005 we will publish the capital note interest rates.

28. We will tackle forcefully the administrative and legal impediments to the development of the banking sector. We will work with the donor community to strengthen the banking sector regulatory and institutional framework. This is a complex issue that requires a greater understanding and implementation of existing laws. We will submit new laws and amendments to parliament, if deemed necessary to support improvements in the financial sector. We will also eliminate the registration fees for deeds, or at least reduce them sufficiently to bring them in line with international standards (end-December 2005 structural benchmark). These fees have proved to be a major deterrent to lending operations associated with immovable property.

29. We are committed to intensifying our efforts to liquidate the former state-owned banks and to restructure the licensed ones. To formalize our decision to liquidate the three former state-owned banks, the Ministry of Finance, as the main shareholder, will issue a statement to that effect by end-September 2005. By this date, the deposits with these former banks will be transferred to licensed banks, or reimbursed. In addition, by end-December 2005, we will appoint liquidators and start implementing the liquidation of these unlicensed banks. Regarding the three licensed state-owned banks, we will assign, by end-December 2005, new management teams, or engage management advisors, to implement their long-term strategic plans (due by end-September 2005). Based on the findings of the review of the performance of these banks under their conditional licenses, DAB will elaborate a new set of conditions and corrective actions to ensure their financial soundness and medium-term profitability.

\section{External Policy and Debt Management}

30. The overall outlook for the external sector looks favorable. The current account deficit excluding grants, is projected to reach 44.8 percent of GDP in 2005/06, down from 45.0 percent of GDP in 2004/05. While foreign direct investment and official borrowing are 
expected to increase further, the financing of this deficit will continue to rely heavily on grant financing. Including grants, the current account is projected to record a surplus equivalent to 0.5 percent of GDP.

31. We will continue to improve the collection and the compilation of balance of payments data. We will strengthen our processes for evaluation of non-recorded trade flows, based on the findings of the current survey of illegal trade flows in Herat and of upcoming surveys in other bordering provinces, including Nangahar, Kandahar, and Balkh. We also intend to ensure extended coverage and consistency of data on grants. For that purpose, DAB will coordinate with the various government agencies and the donor community. DAB will also work closely with the banking community to establish more reliable flows of financial data for balance of payments purposes.

32. Our external debt management strategy will remain cautious as we will continue to rely on grants and loans on highly concessional terms to meet our financing needs. We will press ahead with our efforts for continued support from multilateral and bilateral creditors and donors to ensure medium-term fiscal and external sustainability and the soundness of our financing strategy. We will also continue to seek generous debt relief from existing bilateral creditors.

33. We will pursue our good faith efforts to complete the external debt survey by end-September 2005. We have already requested assistance from the Secretariat of the Paris Club to reconcile debt owed to Paris Club creditors. Regarding the non-Paris Club creditors, we have achieved some success in a number of cases. Nevertheless, others, particularly those involving countries that have since split into several new countries, may require protracted exchanges to achieve debt reconciliation. We would welcome assistance from IMF staff in facilitating contacts between the Ministry of Finance and officials of nonParis Club creditors. Preparatory work on an external debt management strategy is progressing and we expect it to be adopted by Cabinet by end-September 2005 .

\section{E. Structural Reforms}

34. With IMF and other donor assistance, we will pursue our structural reform agenda, including reforms covered by program conditionality. In addition to the reforms introduced in the fiscal and monetary areas already mentioned in this memorandum, we will adopt by end-September 2005 a comprehensive restructuring plan and a classification of state-owned enterprises (SOEs) by planned restructuring method. We will ensure that the retrenchment costs associated with divesting our interest in those SOEs are fiscally sustainable. Consistent with our strategy to divest from commercial activities, we will refrain from creating any new SOE, bank, or financial institution. As regards divestment more generally, we are committed to an open and transparent process that will ensure maximum income to the state from the sale of any state assets. 


\section{F. Poverty Reduction Strategy}

35. We will continue to work on the NDS, so as to complete it by end-December

2005. We have put in place an institutional framework to conduct this process, including an oversight committee of the NDS comprising the ministers of economy, finance, foreign affairs, and rural rehabilitation, and the economic adviser of the President. The oversight committee provides the strategic guidance and coordinates the work of the various participants. A working group is in charge of the technical aspects of the work. The other component of the institutional framework include an External Advisory Group that draws on the expertise and feedback of the United Nations agencies, the international financial institutions, key donors, and civil society. We have also launched an extensive consultation process with donors, various ministries, and civil society, to help identify the key priorities of our poverty reduction strategy building upon our recent work on the Millennium Development Goals. Over the next few months, we will continue our work to improve our social statistical data base and our understanding of the determinants of poverty. We will also focus our attention on the macroeconomic implications of our priorities.

\section{G. Statistical Issues}

36. The building of a strong statistical database remains a pillar of the SMP. Guided by the September 2004 statistical master plan, our priority is to first establish an adequate legal framework for collecting, processing and disseminating economic data. To that end, we are currently working on a statistical law, which is expected to be adopted by Cabinet by end-September 2005. We are also seeking support from the donor community to restructure the Central Statistics Office, reestablish its independence and fund the action plan for the implementation of the statistical master plan. Because of some technical difficulties, we will now launch the three key surveys in September $2005 .^{5}$

\section{H. Technical Assistance and Other Issues}

\section{A comprehensive review of the technical assistance (TA) provided by various} donors is progressing according to schedule and has already led to some initial changes in the use of TA. Ultimately, this review should help the government and the donor community address the distortions and weaknesses identified so far, establish new priorities, and redeploy resources to sectors in need. We reiterate our gratitude to the IMF for the TA it has provided to date. We are looking forward for additional assistance from the IMF to review exchange rate regulations and improve monetary statistics.

\footnotetext{
5 These surveys, which were initially expected to be launched in June/July 2005, are: the national risk vulnerability assessment survey on rural households; the integrated living standard survey on household income and expenditure, and, the integrated business enterprise survey (which will cover a sample of about 1000 medium and large enterprises). These surveys are critical in providing a baseline of which to measure development progress.
} 
38. In July 2005, and after consultation with non-governmental organizations (NGOs) and donors, we adopted a law governing the NGOs. The NGO community has been instrumental in reestablishing delivery of basic services in various parts of the country for many years. The new law provides an adequate framework for efficient NGO and local involvement in the provision of social services. To comply with the new law, all NGOs are expected to re-register before end-December 2005. Another feature of the law is that construction must now be delivered primarily by the private sector, where feasible. Also, to improve information on the coverage of social services by various providers, NGOs must now report on their activities to the Ministry of Economy on a quarterly basis.

\section{Program Monitoring}

39. In monitoring the SMP, we will refer to the definitions, data sources, and frequency of monitoring set out in the attached Technical Memorandum of Understanding (TMU). The quarterly quantitative indicators through end-September 2006 are included in Table 1. The structural benchmarks are set out in Table 2. We realize that a large number of these structural benchmarks are set out for end-September 2005; this mainly reflects a sequencing established prior to the request for an additional 12-month extension of the SMP. Over the next reviews, and if warranted by the need to strengthen program implementation, understandings could be reached on additional structural benchmarks for subsequent quarters through September 2006. For reporting purposes, the government will continue to provide IMF staff all core data, appropriately reconciled and on a timely basis, as specified in the TMU. IMF staff will be notified prior to introducing any policy actions and developments that might affect the program.

40. The Technical Committee of Coordination (TCC) will continue to monitor execution of the SMP and will ensure timely transmission of core data to the IMF. We intend to encourage the TCC to consolidate its analytical capacity, reach out to various government agencies to improve its dissemination of key macroeconomic data. Also, the TCC should be instrumental in working on the macroeconomic component of the upcoming NDS. 


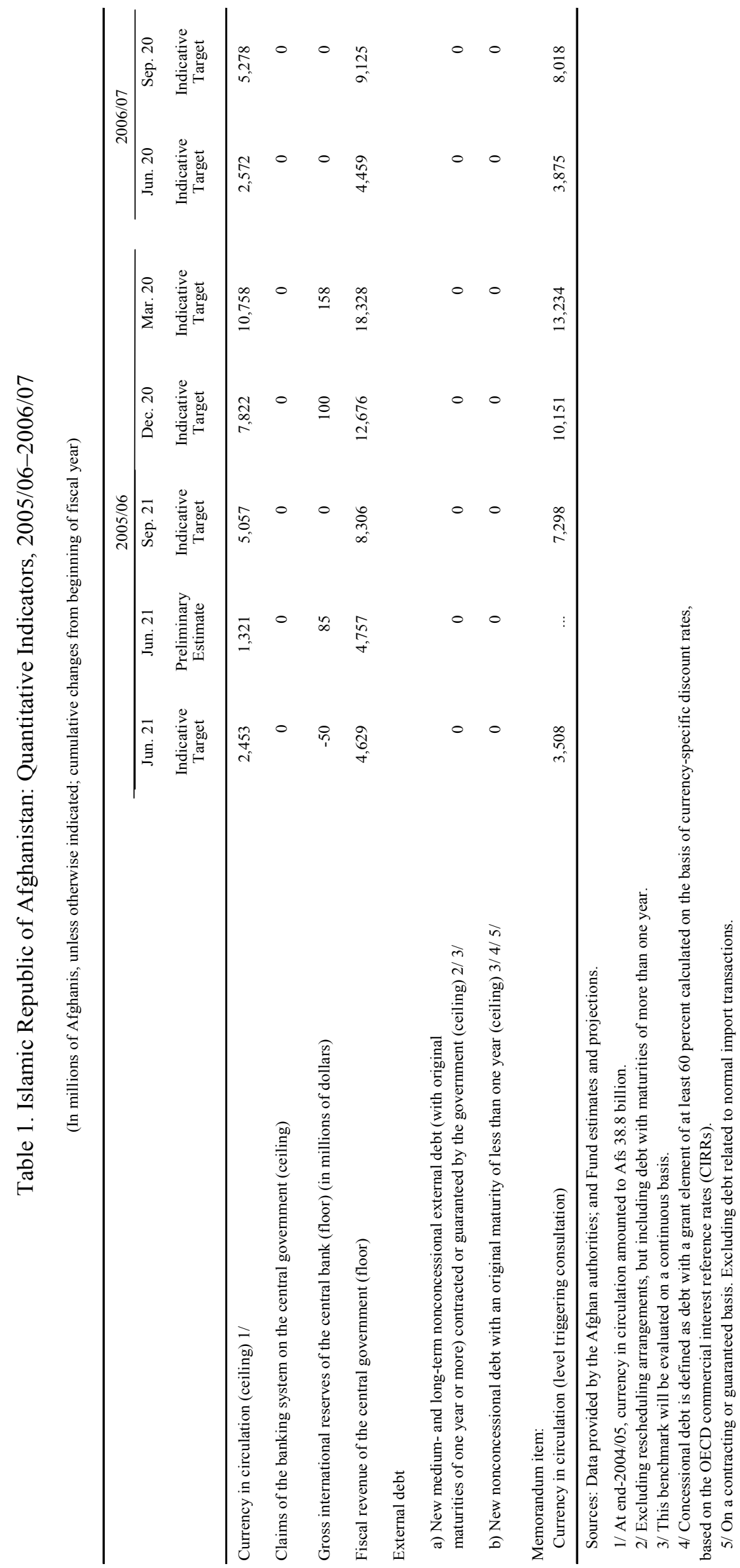




\section{Structural Benchmarks}

Adopt (by the Cabinet) and publish in the Official Gazette the financial management law.

Publish the financial statements of the 2003/04 external audit of DAB.

Reconcile the government accounting records with the government's bank account.

Publish the 2004/05 audited financial statements (core budget).

Adopt (by Cabinet) a comprehensive external debt management strategy.

Contact the Secretariat of the Paris Club to assist with the comprehensive review of, and reconciliation of, debt owed to Paris Club creditors; and continue to contact the non-Paris Club creditors for a full reconciliation of external obligations, including those that did not respond to earlier requests for debt reconciliation.

Publish in the Official Gazette: the proposed amendments to the income tax law to provide for administrative powers and for additional corporate tax reform measures.

Commence implementation of recently approved tax measures, notably the business receipt tax on hotels, restaurants, telecommunications, and airlines and the wage withholding tax, accompanied by a taxpayer education program

Issue a statement indicating the Ministry of Finance decision, as the main shareholder, to liquidate the three former state-owned banks.

Appoint liquidators for the three former state-owned banks and start implementing their liquidation.

Assign new management teams or engage management advisors in the licensed state-owned banks to implement their long-term strategic plans.

Adopt (by Cabinet) a Medium-Term Fiscal Framework that includes (i) a fiscal table with 3-year projections of revenues, expenditures, fiscal deficit and sources of financing, and (ii) a description of the policy actions which sustain the projections.

Eliminate, or reduce substantially, registration fees for deeds.

Remunerate required reserves.

Identify largest taxpayers to be administered by the Large Taxpayer Unit according to agreed transparent criteria, and prepare detailed compliance profile for each taxpayer.
Target Date

Status

End-June 2005

Implemented

End-June 2005

Implemented

End-September 2005

End-September 2005

End-September 2005

End-September 2005

End-September 2005

End-September 2005

End-September 2005

End-December 2005

End-December 2005

End-December 2005

End-December 2005

End-March 2006

End-March 2006 
Table 2. Islamic Republic of Afghanistan: Structural Benchmarks, June 2005-September 2006 (concluded)

\section{Structural Benchmarks}

Target Date

Status

Publish estimate of revenues forgone as a result of customs exemptions, End-March 2006 including due to international assistance, and income tax law exemptions.

Establish appeals process for customs and tax administrations.

End-June 2006

Process gold held in the palace vaults into a form that qualifies as a End-September 2006 reserve asset and transfers any monetary gold held in Afghanistan to an international gold center.

Submit to parliament the core budget's audited financial statements for 2005/06.

End-September 2006 
INTERNATIONAL MONETARY FUND

ISLAMIC REPUBLIC OF AFGHANISTAN

\section{Technical Memorandum of Understanding}

1. This memorandum sets out the understandings between the Afghan authorities and the Fund staff relating to the monitoring of the Staff-Monitored Program (SMP). ${ }^{1}$ It is organized as follows: Section I specifies the quantitative indicative targets; Section II provides definitions of the principal concepts and financial variables; Section III relates to the reporting requirements.

\section{QUANTITATIVE INDICATIVE TARGETS}

2. Monitoring of the implementation of the program will be conducted on the basis of an assessment of the observance by the Government of Afghanistan of the quantitative indicators and structural benchmarks at specified dates.

3. The quantitative indicators are specified in Table 1 of the MEFP and updated MEFPs attached to the letters of March 23, 2004, September 6, 2004, December 29, 2004, February 3, 2005, May 18, 2005, and August 16, 2005. They are as follows:

- $\quad$ a ceiling on currency in circulation of Da Afghanistan Bank (DAB);

- $\quad$ a ceiling on net claims of the banking system on the central government;

- $\quad$ a floor for the build-up of gross international reserves of DAB;

- $\quad$ a floor on fiscal revenue of the central government;

- $\quad$ a ceiling on new medium- and long-term nonconcessional external loans contracted or guaranteed by the government; and

- $\quad$ a ceiling on new nonconcessional debt contracted or guaranteed by the government with an original maturity of less than one year.

\footnotetext{
${ }^{1}$ The SMP initially covered the period March 2004-March 2005. At the request of the authorities, it was extended for six months through September 2005 (IMF Country Report No. 05/128). At the time of the fifth review, the authorities requested an additional 12-month extension through September 2006.
} 


\section{DEFINITIONS}

\section{A. Program Exchange Rate}

4. For purposes of monitoring under the program, a program exchange rate will be used. This program exchange rate will be the average of the U.S. dollar/Afghani buy and sell cash rates, as reported by the DAB as of February 29, 2004 (49.84 Afghanis per U.S. dollar). The program exchange rate will be used to convert into Afghanis the U.S. dollar value of all foreign assets and liabilities denominated in U.S. dollars. For assets and liabilities denominated in SDRs and in foreign currencies other than the U.S. dollar, they will be converted in U.S. dollars at their respective exchange rates prevailing as of February 29, 2004, as published in the International Financial Statistics (IFS).

\section{B. Currency in Circulation}

5. Currency in circulation is defined as total currency (new Afghani) issued by DAB. It excludes currency held in the presidential palace vault, in DAB main vault, and in the vaults of DAB's provincial branches, but includes currency in the vaults of DAB's district branches.

\section{Net Claims of the Banking System on the Government}

6. Net claims of the banking system on the government are defined as the difference between the banking system's claims on the government and the deposits of the government with the banking system.

\section{Gross International Reserves}

7. Gross usable reserves of the DAB are reserve assets, as defined in the balance of payments (BOP) manual, that are controlled by the DAB, are immediately and unconditionally available to the DAB for meeting balance of payments needs, and are not earmarked by the DAB for meeting specific payments. They consist of balances on accounts maintained with overseas correspondent banks, foreign exchange banknotes in the vaults of the DAB, monetary gold, SDRs, and Afghanistan's reserve position in the International Monetary Fund.

\section{E. Nonconcessional Public Sector or Publicly Guaranteed External Debt}

8. Table 1 of the MEFP specifies limits to the contracting or guaranteeing of new external debt by the government. For program purposes, "government" includes the central government, and government departments and official agencies which do not seek profit and whose budgets are issued independent of the annual operational or development budgets. Government and government-guaranteed external debt covers all external debts incurred or guaranteed by the government. 
9. The limits specified in Table 1 of the MEFP apply to the contracting or guaranteeing by the government of new, nonconcessional external debt with an original maturity of more than one year. This limit applies not only to debt as defined in point No. 9 of the Guidelines on Performance Criteria with Respect to Foreign Debt in Fund Arrangements (Decision No. 6230-(79/140), August 3, 1979 as amended by Decision Nos. 11096-(95/100), October 25, 1995, and 12274-(00/85), August 24, 2000), but also to commitments contracted or guaranteed for which value has not been received. Excluded from this limit are leases of real property by Afghan embassies or other foreign representations. External debts will be expressed in U.S. dollar terms, with debts in currencies other than the U.S. dollar converted into U.S. dollars at the market rates of the respective currencies prevailing on February 29, 2004, as published in IFS.

10. The limits specified in Table 1 of the MEFP also apply to the contracting and guaranteeing by the government of new, nonconcessional external debt with an original maturity of one year or less. The term "debt" has the meaning set forth in point No. 9 of the Guidelines on Performance Criteria with Respect to Foreign Debt in Fund Arrangements (adopted by the Executive Board of the International Monetary Fund on August 24, 2000). Excluded from this limit are normal import-related credits. External debts will be expressed in U.S. dollar terms, with debts in currencies other than the U.S. dollar converted into U.S. dollars at the market rates of the respective currencies prevailing on February 29, 2004, as published in IFS.

11. For purposes of the program, the guarantee of a debt arises from any explicit legal obligation of the government or DAB or any other agency acting on behalf of the government to service such a debt in the event of nonpayment by the recipient (involving payments in cash or in kind), or indirectly through any other obligation of the government or DAB to cover a shortfall incurred by the loan recipient.

12. Concessionality will be based on currency-specific discount rates based on the OECD commercial interest reference rates (CIRRs). For loans of an original maturity of at least 15 years, the average of CIRRs over the last 10 years will be used as the discount rate for assessing the concessionality of these loans, while the average of CIRRs of the preceding six-month period will be used to assess the concessionality of loans with original maturities of less than 15 years. To the ten-year and six-month averages of CIRRs, the following margins will be added: 0.75 percent for repayment periods of less than 15 years; 1 percent for 15-19 years; 1.15 percent for 20-30 years; and 1.25 percent for over 29 years. Under this definition of concessionality, only loans with grant element equivalent to 60 percent or more will be excluded from the debt limits. The debt limits will not apply to loans contracted for debt rescheduling or refinancing.

\section{F. Fiscal Revenues of the Central Government}

13. Fiscal revenues of the government include revenues collected in Kabul as well as revenues collected by the provincial offices of the government and transferred to the 
government account at DAB. They include revenues from corporate income tax, personal income tax, business receipts tax, fixed withholding taxes on imports and exports (and creditable against the income tax), presumptive taxes in lieu of the income tax, import duties and other charges and fees (the Chamber of Commerce import/export valuation charge, the Red Crescent fee, permit fees from the Ministry of Commerce, fees and charges from the Ministry of Communication, and over flight fees collected by the Ministry of Civil Aviation). It excludes revenue from privatizations or other sale of state assets, grants, and other direct transfers. It excludes provincial revenues accrued between March 20, 2004 and March 20, 2005 but where funds are not transferred to government's DAB accounts by April 20, 2005. It also excludes revenue accrued before February 21, 2004, even if funds are transferred to government accounts between March 20, 2004 and March 20, 2005. All revenue must be supported by the relevant documentation.

\section{G. Structural Benchmarks}

14. The structural performance benchmarks are specified in Table 2 of the MEFP and updated MEFPs attached to the letters of March 23, 2004, September 6, 2004, December 29, 2004, February 3, 2005, May 18, 2005, and August 16, 2005. They are elaborated further as follows:

- Consolidation of all line ministry accounts into the Treasury Single Account (TSA). All revenue collected by ministries must be deposited into the main government account (including sub-accounts), and no ministry may have its own bank account without the explicit written consent of the Minister of Finance.

- $\quad$ Regular transfer of provincial moustoufiat balances into the TSA at DAB headquarters. Transfers will take place, where possible, on a weekly basis, but at a minimum on a monthly basis. Also the provinces may not make expenditures from their revenue accounts. This will be verified by the records of DAB. For each individual branch, the transferred amount will have to be credited to the TSA within 30 days of the end of each solar month.

- Development of consolidated fiscal accounts including provinces and operating and development budgets. This should be prepared on a monthly basis, with a sixweek lag, for the operating budget, using a functional, ministerial, and economic classification. For the development budget, which would include those transactions that pass through the Treasury, these accounts must be prepared on a quarterly basis, with a six-week lag, using the classification structure under the National Development Framework. Development expenditures implemented directly by donors will be included if data are available.

- Extension of the consumer price index survey to main cities beyond Kabul. This must include at least 5 other cities. 
- Development of a monetary survey, including the balance sheets of commercial banks. The survey is to include only those banks licensed under the new banking law.

- Adoption of presidential decree precluding tax exemptions and concession. Appropriate legal enactment to ensure statutory tax rules prevail over nonstatutory concessions in agreements.

- $\quad$ Publish (by the Ministry of Finance) in a quarterly basis fiscal data. The data should be at least quarterly, but whenever possible, should include monthly revenue and expenditures (center and by individual province) covered under the core budget, as well as financing. The structure of the revenue and expenditure data should be on the same classification as the approved budget. The data should also compare outturns against the budget. As information on the external budget depends on cooperation from the donors, the government should make a "best effort" to compile the data, and make ongoing revisions. Published data should also include principal and interest payments on external government and government-guaranteed debt, and disbursement of external loans. Publication of this information can be in either electronic or paper format.

- Complete an assessment of the financial position of the SOE. Adopt (by Cabinet) (i) the list classifying SOEs according to proposed economic restructuring method; and (ii) the Economic Restructuring Plan. For those nonfinancial SOEs with poor record keeping and scarce financial information, instead of an assessment of the financial position, the experts will make, at a minimum, an informed judgment of the state of the enterprise through in-site visits and thorough discussions with management and staff. If sufficient financial information becomes available, then a full-fledged assessment of the financial position of the SOE will be conducted prior to its restructuring. The Economic Restructuring Plan will reflect the various steps and tasks entailed by the restructuring process, and will be adopted by the Ministries in charge of the SOEs and presented to the Cabinet.

- Transfer to other entities all DAB commercial activities that are inconsistent with the central bank and commercial bank laws. At a minimum, this will include all commercial activities performed by DAB's main office. Notwithstanding the transfer of other commercial activities, the transfer of commercial accounts will, at least, comprise all accounts which are not: frozen; non-cash; or requiring audit or/and legal determination.

- Improve government payments by initiating (i) direct electronic payments to vendor bank accounts; and (ii) a pilot for direct salary deposits to bank accounts for the employees of three ministries. The benchmark is amended to read as follows: "Improve government payments by initiating (i) direct electronic payments 
to vendor bank accounts; and (ii) a pilot for direct salary payments for the employees of three ministries".

- $\quad$ Reconcile government fiscal and banking records. The reconciliation will cover all core budget operations (recorded with AFMIS) and associated banking data from the beginning of 2005/06. It will be undertaken at least monthly. A reconciliation that leaves unexplained differences up to 5 percent of total core expenditures between the banking and accounting records will not meet the benchmark.

- A Medium-Term Fiscal Framework (MTFF) typically contains a statement of fiscal policy objectives and a set of integrated medium-term macroeconomic and fiscal targets and projections. The next step, which would be supported by the ANDS, would be to develop medium-term budget estimates for spending agencies to link, in broad terms, the allocation of resources to the government's strategic priorities, while ensuring overall fiscal discipline. The MTFF should include (i) a fiscal table with 3-year projections of revenues, expenditures, fiscal deficit and sources of financing, and (ii) a concise description of the policy actions which sustain the projections, particularly for revenues, the wage bill, the profile of actual development expenditures (not just commitments) and the fiscal deficit(s), consistent with international definitions. Detailed sector plans or costings are not required.

\section{Provision of Information to the Fund StafF}

\section{A. Data}

15. To permit the monitoring of developments under the program, the government will provide to Division A of the Middle Eastern and Central Asia Department (MCD), through the office of the Resident Representative of the IMF in Afghanistan, the information specified below and summarized in the list of reporting tables provided by Fund staff to the Technical Committee. The program is designed with quarterly quantitative targets and the actual outcome should be provided within six weeks following the end of the quarter. However, in order to facilitate regular monitoring, many of the indicators should be provided with the frequencies indicated below.

- $\quad$ DAB gross foreign exchange reserves (weekly) from March 20, 2004. This should be reported no longer than 2 weeks after the end of the week.

- Monetary statistics, including exchange rate data (daily), government accounts with the DAB and currency in circulation (monthly) from March 20, 2004. From September 21, 2004, monetary statistics will also include a monetary survey (monthly), including balance sheets of DAB and a balance sheet of the commercial banks. This should be reported no longer than 3 weeks after the end of the month.

- $\quad$ Foreign trade statistics (imports, exports, reexports) (quarterly) from March 20, 2004. This should be reported no longer than 8 weeks after the end of the quarter. 
- $\quad$ Operational budget operations and their financing should be reported on a monthly basis no more than 4 weeks after the end of the month.

- $\quad$ Detailed data on foreign grants and loans disbursed, contracted, or guaranteed by the central government; foreign debt amortization and interest payments, including new external arrears (if any); and total outstanding amount of arrears (quarterly) from March 20, 2004.

- List of short, medium, and long-term government or government-guaranteed external loans contracted during each quarter; identifying for each loan: the creditor, the borrower, the amount and currency, the maturity and grace period, and interest rate arrangements (quarterly) from March 20, 2004.

- $\quad$ National accounts data (quarterly) from March 20, 2004. This should be reported no longer than 8 weeks after the end of the quarter.

- $\quad$ Consumer price index (CPI) for the city of Kabul (monthly) from March 20, 2004; then starting in October 2004, CPI covering 5 major cities (monthly). These should be reported no longer than 4 weeks after the end of the month.

- $\quad$ Core development budget operations and their financing should be reported on a quarterly basis no more than 6 weeks after the end of the quarter. The data should be at least quarterly, but whenever possible, should include monthly expenditures covered under the core budget, as well as financing. The structure of the financing (grants and loans) and expenditure data should be on the same classification as the operating budget in addition to the program classification used by the budget. The data should also compare outturns against the budget.

\section{B. Structural Reforms}

16. Review of the structural reforms. The Government of Afghanistan will prepare and send to the IMF reports, with appropriate documentation, indicating progress achieved, explaining any deviations relative to the initial planning, and specifying expected revised completion date.

\section{State-Owned Banks}

17. The authorities will provide staff with relevant documents and information dealing with the proceedings associated with the relicensing and/or closure and resolution of commercial banks.

\section{Other Information}

18. Other details on major economic and social measures taken by the government that are expected to have an impact on program sequencing (such as changes in legislation, 
regulations, or any other pertinent document) will be sent in a timely manner to IMF staff, for consultation or information.

19. The Technical Committee of Coordination (TCC) will provide Division A of the Middle East and Central Asia Department with any other information that may be required by the staff of the IMF for the effective monitoring of the program.

\section{E. Program Monitoring}

20. For the purposes of program monitoring, working meetings are planned, at least bi-weekly, with the participation of representatives of the MoF, the DAB, the TCC, and the IMF resident representative. 